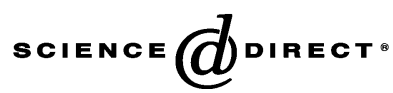

Earth-Science Reviews 68 (2005) 281-315

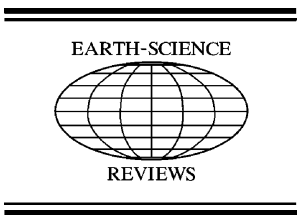

www.elsevier.com/locate/earscirev

\title{
From greenhouse to icehouse; organic-walled dinoflagellate cysts as paleoenvironmental indicators in the Paleogene
}

\author{
Appy Sluijs $^{\mathrm{a}, *}$, Jörg Pross ${ }^{\mathrm{a}, \mathrm{b}, \mathrm{c}}$, Henk Brinkhuis ${ }^{\mathrm{a}}$ \\ ${ }^{a}$ Laboratory of Palaeobotany and Palynology, Utrecht University, Budapestlaan 4, NL-3584 CD Utrecht, The Netherlands \\ ${ }^{\mathrm{b}}$ Institute of Geosciences, Tübingen University, Sigwartstraße 10, D-72076 Tübingen, Germany \\ ${ }^{\mathrm{c}}$ Institute of Geology and Paleontology, Frankfurt University, Senckenberganlage 32-34, D-60054 Frankfurt, Germany
}

Received 27 May 2004

\begin{abstract}
Dinoflagellates are an important component of the extant eukaryotic plankton. Their organic-walled, hypnozygotic cysts (dinocysts) provide a rich, albeit incomplete, history of the group in ancient sediments. Building on pioneering studies of the late 1970s and 1980s, recent drilling in the Southern Ocean has provided a wealth of new dinocyst data spanning the entire Paleogene. Such multidisciplinary studies have been instrumental in refining existing and furnishing new concepts of Paleogene paleoenvironmental and paleoclimatic reconstructions by means of dinocysts.

Because dinocysts notably exhibit high abundances in neritic settings, dinocyst-based environmental and paleoclimatic information is important and complementary to the data derived from typically more offshore groups as planktonic foraminifera, coccolithophorids, diatoms and radiolaria. By presenting case-studies from around the globe, this contribution provides a concise review of our present understanding of the paleoenvironmental significance of dinocysts in the Paleogene (65-25 Ma). Representing Earth's greenhouse-icehouse transition, this episode holds the key to the understanding of extreme transient climatic change. We discuss the potential of dinocysts for the reconstruction of Paleogene sea-surface productivity, temperature, salinity, stratification and paleo-oxygenation along with their application in sequence stratigraphy, oceanic circulation and general watermass reconstructions.
\end{abstract}

(C) 2004 Elsevier B.V. All rights reserved.

Keywords: (Marine) eukaryotic plankton; Dinoflagellates; Organic-walled hypnozygotic dinoflagellate cysts; Paleoenvironment; Paleoclimate; Paleogene; Paleocene; Eocene; Oligocene

\section{Introduction}

The Paleogene has by now emerged as representing a climatically highly dynamic period, which involved the Earth's transformation from a greenhouse to an

* Corresponding author. Tel.: +31-30-253-2638; fax: +31-30253-5096.

E-mail addresses: A.Sluijs@bio.uu.nl (A. Sluijs), joerg.pross@uni-tuebingen.de (J. Pross),H.Brinkhuis@bio.uu.nl (H. Brinkhuis). icehouse state. It has become increasingly apparent that this transformation was not gradual, but instead was characterized by numerous extreme transient climatic events (see Zachos et al., 2001 for an overview). It has become generally appreciated that dinocyst paleoenvironmental analysis is a key element in understanding Paleogene paleoceanographic change and climate dynamics.

Dinoflagellates are single-celled, predominantly marine, eukaryotic plankton that typically occur as 
motile cells in surface waters (e.g., Fensome et al., 1996a), sometimes in astonishing concentrations (e.g., 'red tides'). Although most dinoflagellates are autotrophic, many dinoflagellates have heterotrophic lifestyles and may rank among the zooplankton. As part of their-often complex - life cycle, some dinoflagellates produce preservable organic-walled hypnozygotic resting cysts (dinocysts). In addition, (mainly vegetative) calcareous and siliceous cysts are known. The cyst part of the dinoflagellate life cycle is usually associated with sexual reproduction and is induced by particular surface water parameters, predominantly seasonal nutrient depletion, that only prevail for a brief period (Taylor, 1987). Typically, the motile stage does not preserve, but organic dinocysts are found from the late Triassic onwards (e.g., MacRae et al., 1996 and references therein).

Together with diatoms and coccolithophorids, dinoflagellates are among the most prominent marine primary producers in the oceans today and, as such, play an important role in the global carbon cycle (e.g., Brasier, 1985). Moreover, they were probably an important factor in the development of coral reef systems; the ecological success of scleractinian corals since the Triassic was probably a direct result of their acquisition of dinoflagellate symbionts, which allowed them to exploit nutrient-poor environments (Haeckel, 1894; Trench, 1987). Dinoflagellate symbionts are also known from some groups of extant and fossil planktonic foraminifera (e.g., Spero, 1987).

The strong interest in dinoflagellates also has economic reasons. In addition to their position at or near the base of the marine food chain, modern dinoflagellates are known to cause massive fish kills (e.g., Heil et al., 2001; Cembella et al., 2002), paralytic shellfish poisoning in humans, and constitute other harmful algal blooms (e.g., Backer et al., 2003). The high economic impact of these phenomena has stimulated extensive research in order to develop preventive measures (e.g., Taylor and Seliger, 1979; Hallegraeff, 1993; Fogg, 2002; abstracts in Matsuoka et al., 2003). Over the past decades, the importance of dinocyst analysis has been increasingly recognized in hydrocarbon exploration where dinocyst biostratigraphy has now emerged as a routine tool (see, e.g., Stover et al., 1996; Williams et al., 2004, for a summary of existing Triassic to Neogene dinocyst biozonations). In many oil and gas provinces, such as the Paleogene of the North Sea Basin, they have yielded a higher stratigraphic resolution than calcareous microfossils (e.g., Gradstein et al., 1992). Remains of dinoflagellates are also major components of petroleum source rocks (Ayres et al., 1982) due to their ability to store lipids (Bold, 1973; Horner, 1985).

Over the past 30 years, organic-walled dinocysts have been increasingly employed as sensitive (paleo-) environmental indicators (e.g., Downie et al., 1971; Mudie and Harland, 1996; Wall et al., 1977; see overviews in, e.g., Dale, 1996; Pross et al., 2004). Generally, dinocyst (paleo-)ecology is best understood for Quaternary assemblages due to the high number of extant taxa that can be studied following an actuo-paleontological approach (e.g., Turon, 1981; Harland, 1983; de Vernal and Mudie, 1992; Harland and Long, 1996; Dale, 1996, 2001; Rochon et al., 1999; Targarona et al., 2000; Boessenkool et al., 2001; Marret and Scourse, 2002; Sangiorgi et al., 2002, 2003; Sprangers et al., 2004; see Matthiessen et al., submitted for publication for a detailed discussion). Such Quaternary studies have shown that organic walled cyst-producing dinoflagellates are indeed highly sensitive to even small changes in surface water characters. As the number of extant dinocysts decreases back in time, the process of relating dinocyst taxa to specific environmental parameters becomes more difficult for pre-Quaternary assemblages. Despite this drawback, building on actuo- and Quaternary studies, dinocyst-based 'deep time' paleoenvironmental reconstructions have become increasingly more realistic and sophisticated over the past decades. Moreover, recent ocean drilling, e.g., in the Southern Ocean, has provided a wealth of Paleogene dinocyst data boosting more integrated, multidisciplinary studies and interpretations (Brinkhuis et al., 2003a,b; Sluijs et al., 2003; Röhl et al., in press(a,b); Schellenberg et al., in press; Williams et al., 2004; Huber et al., in press; van Simaeys et al., submitted for publication; Stickley et al., in press). These and similar other recent efforts have led to considerable progress in Paleogene dinocyst paleoecology.

Considering the above, we here aim to provide a concise review of applied methodologies and illustrate the environmental and climatic signals currently recognized through Paleogene dinocyst studies, often also utilizing Quaternary examples. For this purpose, 
we present a selection of Paleogene case studies from the northern and southern hemispheres, and include a brief introduction into the nature of the fossil dinocyst record.

\section{The fossil dinoflagellate record}

The earliest organic-walled cysts with firmly established dinoflagellate affinity are found in the mid-Triassic. To date, the oldest records have been described from Australia (late Anisian: Nicoll and Foster, 1994, Anisian/Ladinian: Helby and Stover in Goodman, 1987) and Arctic Canada (possibly late Early Triassic: Sarjeant in Goodman, 1987). Because first lower-latitude records are slightly younger (early Carnian; Hochuli and Frank, 2000), it has been hypothesized that dinoflagellates forming organicwalled cysts developed in high-latitude settings (Stover et al., 1996). Biogeochemical evidence, however, suggests an origin of the dinoflagellate lineage in the Precambrian or early Cambrian (Fensome et al., 1996b; Moldowan and Talyzina, 1998). The late Silurian Arpylorus, long considered to be the earliest dinophycean cyst (Sarjeant, 1978), has recently been demonstrated not to be of dinoflagellate affinity and is probably an arthropod remain (LeHérissé et al., 2000).

While Triassic and early Jurassic cyst assemblages exhibit low species diversity and relatively simple

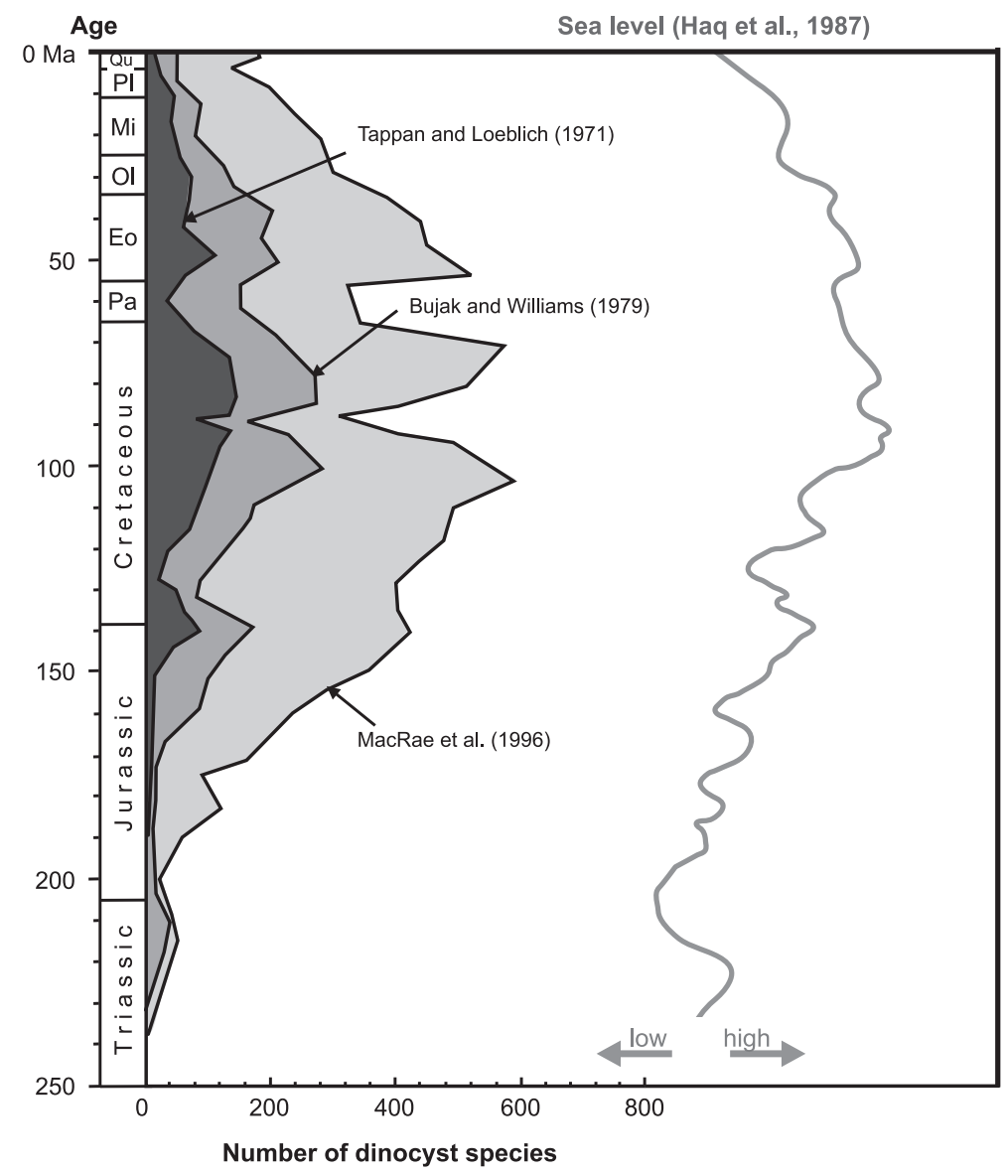

Fig. 1. Dinocyst diversity through the Mesozoic and Cenozoic. The concurrence with the sea level curve of Haq et al. (1987) has been proposed to be the result of the positive correlation between sea level and the degree of ecological variance in shelfal environments. Modified from MacRae et al. (1996). 
cyst morphologies, there is a strong increase in both diversity and morphological complexity during the mid and late Jurassic (Tappan and Loeblich, 1971; Bujak and Williams, 1979; MacRae et al., 1996). This apparent reflection of evolutionary radiation extends well into the Cretaceous and can be visualized by plotting the number of cyst-based species for each age (Fig. 1). This plot shows diversity peaks in the midCretaceous Albian (ca. 580 species), late Cretaceous Maastrichtian (ca. 570 species) and in the early Eocene (ca. 520 species). From the Eocene onward, the number of species declined steadily towards the modern value of 150-175 (MacRae et al., 1996; Head, 1996). The overall character of the cyst-diversity plot shows a strong correlation with the sea level curve of Haq et al. (1987), with high diversity corresponding to intervals of high sea levels and large shelf seas. This correlation probably reflects the higher ecological variance in shelfal settings as compared to open marine environments, allowing higher diversity among shelf-inhabiting groups, such as the organic-walled cyst producing dinoflagellates. It is worth noting, however, that dinocyst taxonomy is purely based on cyst-morphology. Since fossil cysts represent only a surviving structure of part of the life cycle of dinoflagellates (Fensome et al., 1996a), this taxonomy is artificial. Cysts of extant dinoflagellates can be traced back to the motile stage (theca) through laboratory experiments. The studies cited above refer to the cyst-based species numbers. These do not necessarily reflect the number of biological species because several modern dinoflagellate species are known to produce various cyst morphotypes depending on the physiochemical parameters of the water mass in which the theca develops. Furthermore, the cyst-based dinoflagellate 'diversity curve' is strongly biased by the species concepts of different authors. It is also strongly biased towards intervals and areas where there has been extensive hydrocarbon exploration. Moreover, it should be stressed that a diversity record of 'dinocysts' does not relate to the diversity of the group in general. Today, some 2000 species of aquatic dinoflagellates have been described from the Recent, while only a fraction ( $\sim 15 \%$, Head, 1996) of these include the formation of preservable organicwalled cysts as an obligatory part of their life cycle.

Although the fossil dinocyst record is primarily a marine one, Cretaceous and Cenozoic freshwater cyst assemblages are well known from a multitude of localities (e.g., Krutzsch, 1962; Batten and Lister, 1988; Batten et al., 1999). To date, the oldest unequivocal freshwater or brackish water cysts have been described from the late Jurassic/early Cretaceous of Australia (Backhouse, 1988). An even earlier appearance of freshwater dinoflagellates is suggested by nearly monospecific assemblages of suessioid cysts in the upper Triassic (Norian) of Germany (W. Wille, pers. comm., 2001).

\section{Productivity trends}

Reconstructions of eukaryotic productivity patterns in marine environments are of great interest because they are directly linked to important climate characteristics such as surface current patterns, upwelling systems, water mass mixing, surface winds and the global carbon cycle (e.g., Berger et al., 1989; Bertrand et al., 1996). For the reconstruction of marine eukaryotic productivity, both geochemical (e.g., Shimmield, 1992) and micropaleontological approaches are available. Information based on micropaleontological data has traditionally been obtained from benthic and planktic foraminifera, coccolithophorids, diatoms and radiolaria. However, the applicability of these groups for deciphering marine productivity is limited by the fact that most of their representatives occur in open marine environments. Hence, they render only little information on neritic settings where a major portion of modern marine primary productivity originates (Dale and Fjellså, 1994). Moreover, all the remains of these other groups are mineralized and thus prone to chemical dissolution, which limits their utility in paleoceanographic reconstructions, especially at high latitudes (de Vernal and Mudie, 1992). These restrictions do not apply to organic-walled dinocysts, although oxidation may hamper their recovery (see, e.g., Versteegh and Zonneveld, 2002; Reichart and Brinkhuis, 2003). They are not only abundant in neritic settings and resistant to chemical dissolution, but also extremely sensitive to even small changes in nutrient availability (e.g., Dale, 1996). Thus, they provide a promising tool for the reconstruction of productivity.

To date, dinocyst-based identification of productivity variations in the Paleogene strongly relies on changes in the ratio of peridinioid $(\mathrm{P})$ versus gonyaula- 
coid (G) cysts of dinocyst assemblages. This approach, which has its basis in observations on Quaternary dinocyst assemblages (e.g., see overview in Reichart and Brinkhuis, 2003), is founded on the different lifestyles and feeding strategies in dinoflagellates forming peridinioid and gonyaulacoid cysts. Using Modern Protoperidinium as an analog, P-cysts are considered to predominantly represent heterotrophic dinoflagellates that predominantly thrive on diatoms, whereas Gcysts mainly represent autotrophic dinoflagellates (e.g., Powell et al., 1992). This approach has however been criticised for various reasons (e.g., Dale and Fjellså, 1994). Most importantly, not all living peridinioid dinoflagellates are heterotrophic and the same holds probably true for extinct peridinioids (Dale and Fjellså, 1994). Because it is the heterotrophic rather than the peridinioid dinoflagellates that indicate eutrophic conditions, the assumption of a complete equivalence between the terms "peridinioid" and "heterotrophic" is a simplification that may produce erroneous results. Hence, Dale and Fjellså (1994) and Dale (1996) proposed the terms "H-cysts" and "A-cysts" for the cysts of heterotrophic and autotrophic dinoflagellates, respectively. Moreover, Dale and Fjellså (1994) drew attention to the fact that modern heterotrophic dinoflagellates also occur in places other than high productivity regions, such as sea-ice dominated settings, which could also lead to the misidentification of eutrophic areas (or to the identification of sea-ice). Despite these drawbacks, approaches to identify paleoproductivity trends in the Paleogene based on the feeding strategies of most peridinioid and gonyaulacoid dinoflagellates have been successfully applied. Even if an unknown portion of P-cysts do represent autotrophic rather than heterotrophic dinoflagellates, peridinioids still represent the closest approximation to heterotrophic dinoflagellates and can thus be used to reconstruct productivity.

Note that the concept of a G/P ratio was first introduced by Harland (1973) using the number of species. He suggested that low $\mathrm{G} / \mathrm{P}$ values were associated with significant freshwater input. In later studies, some authors applied this G/P ratio but confused the number of species with the number of specimens (e.g., Hultberg, 1987).

The potential and limitations of dinocysts as productivity indicators in the Paleogene are discussed in the following paragraphs. For the benefit of clarity, different aspects of productivity reconstructions (coastal settings, upwelling areas and open-ocean settings) are discussed separately.

\subsection{Productivity in coastal and neritic settings}

Dinocysts have been shown to yield a productivity signal in coastal and neritic settings of the Paleogene. Here, the abundance (specimens) of P-cysts (considered to represent predominantly heterotrophic dinoflagellates feeding on diatoms, other phytoplankton and organic detritus) plays a major role. For instance, Crouch (2001) and Crouch et al. (2003b) reconstructed productivity changes in neritic settings from the Paleocene/Eocene boundary interval in New Zealand based on the percentage of peridinioids (Fig. 2). High abundances of P-cysts were used to indicate phases of enhanced nutrient availability probably derived from stronger terrigenous input. Similar approaches were taken by, e.g., Eshet et al. (1994), Brinkhuis et al. (1998), van Mourik and Brinkhuis (2000) and van Mourik et al. (2001). In a related study on the dinocyst record of the Paleocene-Eocene Thermal Maximum (PETM), Crouch (2001) and Crouch et al. (2003a,b) recorded an acme of the tropical genus Apectodinium co-occurring with the prominent PETM negative carbon isotope excursion (Fig. 3). The Apectodinium event has been recorded in sections from the North Sea (Bujak and Brinkhuis, 1998 and references therein, Steurbaut et al., 2003), Greenland, Spitsbergen (e.g., Boulter and Manum, 1989; Nohr-Hansen, 2003), the Tethyan Ocean (N Africa, Austria, Tunisia, Uzbekistan, Pakistan, India; e.g., Köthe et al., 1988; Bujak and Brinkhuis, 1998; Crouch et al., 2003a), equatorial Africa (Jan du Chêne and Adediran, 1984), the eastern (e.g., Edwards, 1989) and northwestern U.S. (J. Lucas-Clark, pers. comm., 2003), Barents Sea, South America (Brinkhuis, pers. obs.) and New Zealand (Crouch, 2001), and is thus shown to be global in nature (Crouch et al., 2001). Although its paleoceanographic nature is not yet fully understood, the Apectodinium acme appears to be related to globally high sea-surface temperatures and a strong increase in nutrient availability in marginal marine settings (Crouch et al., 2001, 2003a). The latter view is based on the concept that the motile dinoflagellates forming Apectodinium cysts were probably heterotrophic and fed on organic 


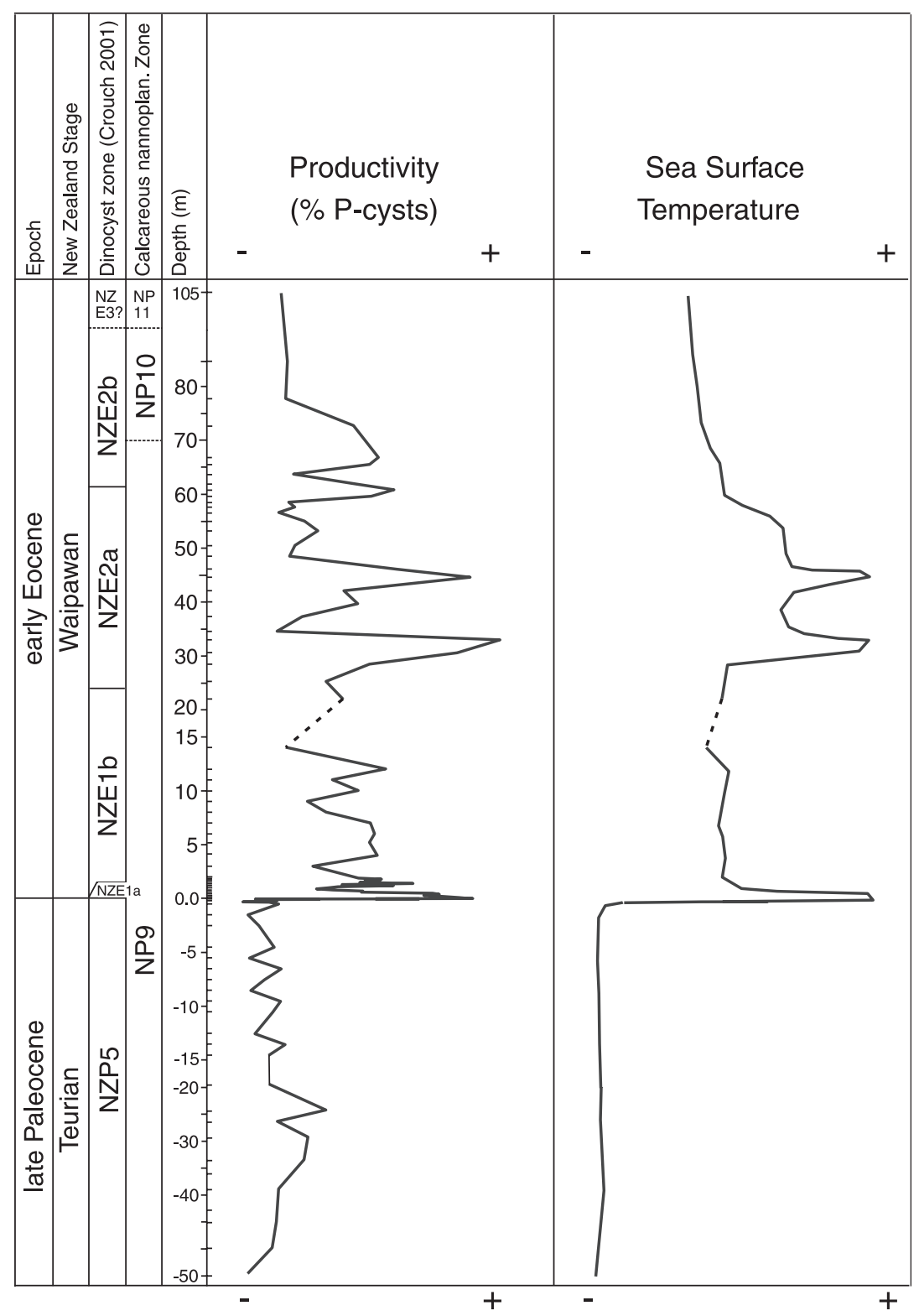

Fig. 2. Dinocyst-based SST and productivity reconstructions across the Paleocene-Eocene transition at the Tawanui section in New Zealand. The SST reconstruction is based on the percentage of species thought to be derived from low latitudes, whereas the productivity reconstruction is based on the percentage of peridinoiod (P) cysts. Modified from Crouch (2001).

detritus or other plankton that occurred in high abundances in marginal marine settings during this time interval. It is in agreement with other studies that show evidence of increased coastal productivity during the PETM (e.g., Speijer et al., 1996; Gavrilov et al., 2003).
Enhanced coastal and neritic productivity has also been reconstructed based on increased abundances of peridiniacean genera such as Wetzeliella spp. and Deflandrea spp. (e.g., Williams, 1977; Köthe, 1990; Brinkhuis, 1994; Brinkhuis et al., 1992; Powell et al., 1996; Firth, 1996; van Mourik et al., 2001). The high 
ANTHERING SECTION, AUSTRIA

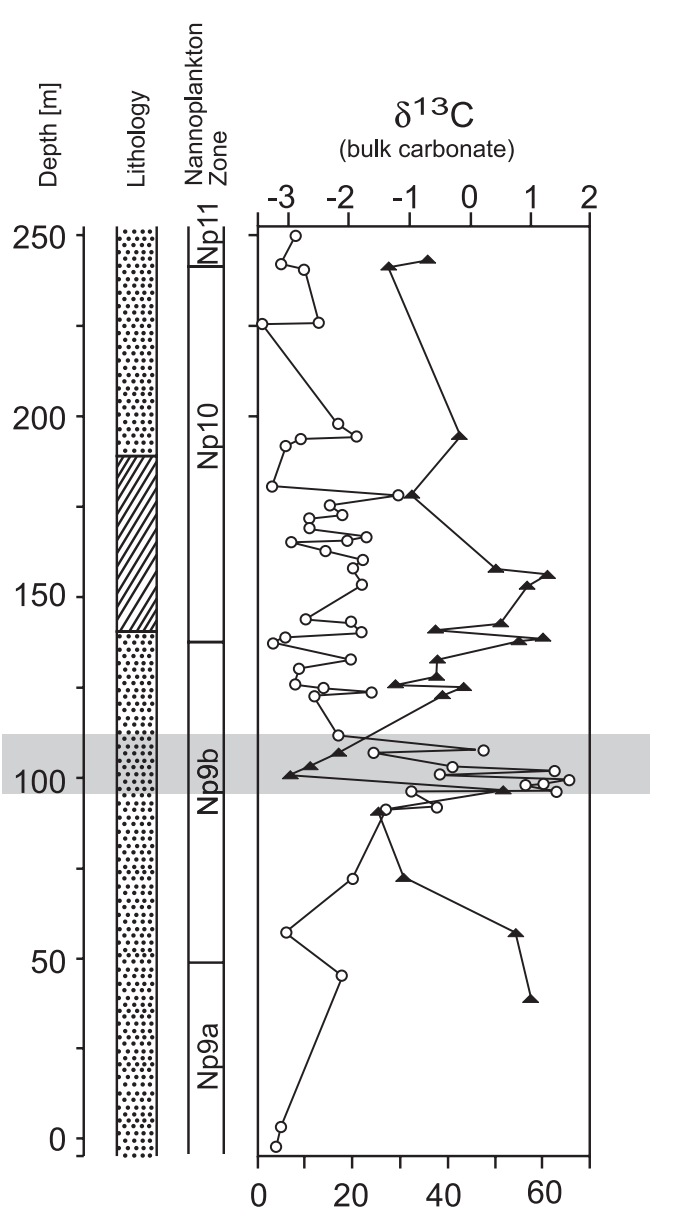

TAWANUI SECTION, NEW ZEALAND
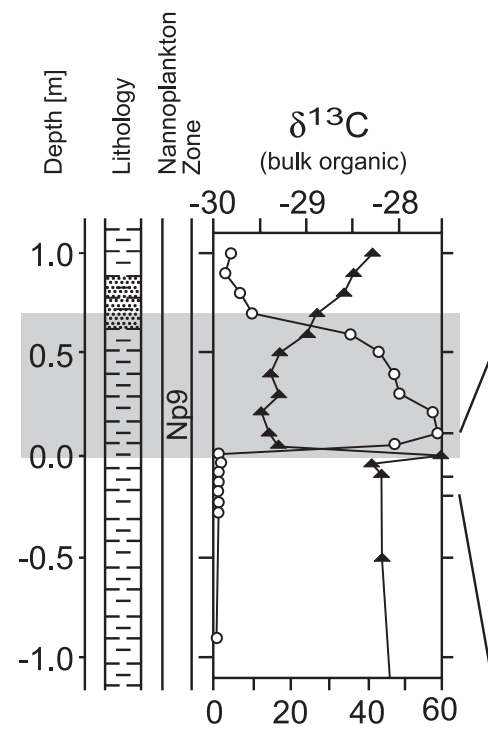

[\%] Apectodinium

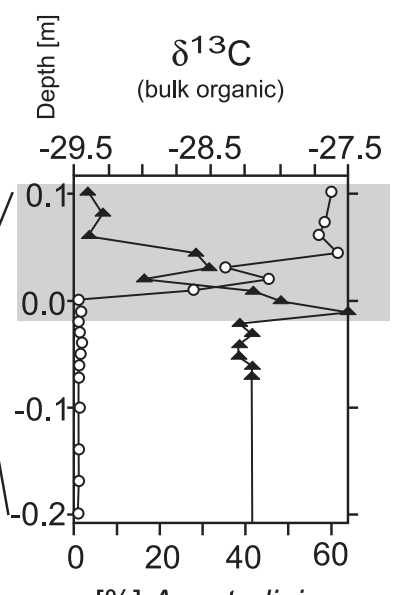

[\%] Apectodinium

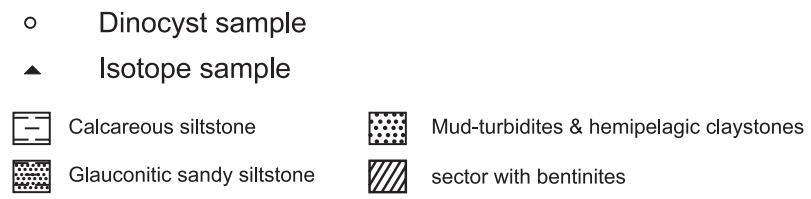

[\%] Apectodinium

Fig. 3. Distribution of Apectodinium percentage and $\delta^{13} \mathrm{C}$ isotope records through the Paleocene-Eocene transition from the Anthering section, Austria (left) and the Tawanui section, New Zealand (right). Shaded areas indicate Apectodinium-dominated dinocyst assemblages coincident with the carbon isotope minimum characterizing the PETM. Modified from Crouch et al. (2001).

abundance of these taxa in nutrient-rich environments may be due to a heterotrophic feeding strategy, as has been postulated based on the close morphological relationship of peridiniacean taxa with present-day Protoperidinium cysts, differing mainly in the number of cingular plates (Brinkhuis et al., 1992). In a multiproxy study on marginal marine middle Eocene deposits in the Southern Ocean, Röhl et al. (in press-b) found that high abundances of Deflandrea spp. (sometimes monospecific) correspond to $\mathrm{CaCO}_{3}^{-}$ depleted sediments and an inshore, possibly brackish, eutrophic setting (see discussions below).

In a study on early Oligocene dinocyst assemblage variations from an epeiric setting in southern Germany, Pross and Schmiedl (2002) applied a statistical approach to identify productivity changes. The dinocyst dataset was subjected to Q-mode principal component analysis. The chosen four-component model explains $78.0 \%$ of the total variance of the dataset. The peridiniacean genera Deflandrea, Rhom- 
bodinium and Wetzeliella, which are often used as productivity indicators (see above), plotted seperately from the monospecific Thalassiphora pelagica assemblage and exhibit highest factor loadings in samples below and above horizons dominated by the $T$. pelagica assemblage. Pross and Schmiedl (2002) interpreted high factor loadings of the $T$. pelagica assemblage to represent periods of enhanced stratification, eutrophication and productivity in the upper water column, and/or oxygen depletion in the lower water column (compare to Vonhof et al., 2000; Coccioni et al., 2000; see also discussion below). Increased abundances of Deflandrea, Rhombodinium and Wetzeliella are probably also linked to elevated nutrient availability, but in well-mixed waters rather than stratified (coastal) waters. Hence, it appears that dinocyst analysis can also yield information on productivity changes that are related to the structure of the water column.

\subsection{Productivity in oceanic upwelling areas}

Upwelling is an important component of the marine circulation pattern. Because areas of upwelling are connected to increased nutrient availability, they represent a prime source of biological productivity in today's oceans. Moreover, upwelling systems have climatic significance. On a global scale, they play an important role in the partitioning of $\mathrm{CO}_{2}$ between the ocean and atmosphere, thus affecting the concentration of atmospheric greenhouse gases (e.g., Sarnthein et al., 1988). On a regional scale, they exert a strong control on the atmospheric moisture flux to adjacent land masses (e.g., Rognon and Coudé-Gaussen, 1996). In turn, upwelling areas are the result of oceanic or atmospheric circulation features and may be used for the reconstruction of these patterns. The identification of upwelling in the sedimentary record plays an important role in paleoproductivity and paleoclimate studies. Due to the upwelling-related formation of phosphate deposits, they also have economic significance.

Dinocyst-based identification of upwelling regions in the Paleogene uses the $\mathrm{P} / \mathrm{G}$ cyst ratio of dinocyst assemblages is used in a similar manner to the reconstruction of productivity in proximal settings. In an analysis of high-latitude North Atlantic dinocyst assemblages from the Eocene and early Oligocene,
Firth (1996) reconstructed paleoproductivity events, possibly caused by upwelling, from the distribution patterns of Deflandrea spp. and Phthanoperidinium spp. The correlation between abundance peaks of these two genera and diatom- and radiolarian-rich biosiliceous oozes (high abundances of diatoms and radiolarians are among the primary food sources for present-day heterotrophic dinoflagellates) supports the idea that dinoflagellates forming Deflandrea and Phthanoperidinium cysts may have been heterotrophic (cf. Brinkhuis et al., 1992), and allows reconstruction of high-productivity episodes in intervals where primary biosilica is not preserved.

Records indicating oceanic upwelling in the Paleogene of the Southern Ocean are largely absent. High relative abundances of peridinioid cysts in the spatially relatively well covered Paleocene and Eocene in this region are usually interpreted to reflect a supply of nutrients from land (e.g., Goodman and Ford, 1983; Wrenn and Hart, 1988; Mao and Mohr, 1995; Brinkhuis et al., 2003b; Sluijs et al., 2003). The scarcity of data that suggest Paleogene upwelling in the Southern Ocean could be due to a relatively sparse geographical and temporal resolution of existing datasets, along with the primarily shallow marine setting studied thus far. Alternatively, this situation may indicate that upwelling intensity in the early Paleogene of the Southern Ocean was indeed relatively low. Unraveling the Paleogene upwelling history of the Southern Ocean using dinocyst analysis has so far been hindered by (1) the absence of data from deep water sites and (2) the absence of early Oligocene records altogether as a result of winnowing by the initiation of strong bottom-water currents related to the onset of Antarctic glaciation, and/or the opening of deep Southern Ocean gateways (see discussions in McMinn, 1995; Brinkhuis et al., 2003a,b).

The abovementioned studies indicate that the relative and absolute numbers of peridinioid cysts can provide information about (changes in) trophic levels of ancient water masses. However, $\mathrm{P} / \mathrm{G}$ ratios do not allow to distinguish between upwelling-related and runoff-related productivity. Hence, the $P / G$ signal may potentially lead to paleoenvironmental misinterpretations. This problem can be reduced if dinocyst datasets are considered from multiple perspectives and interpretations are based on an inter- 
Site 1172

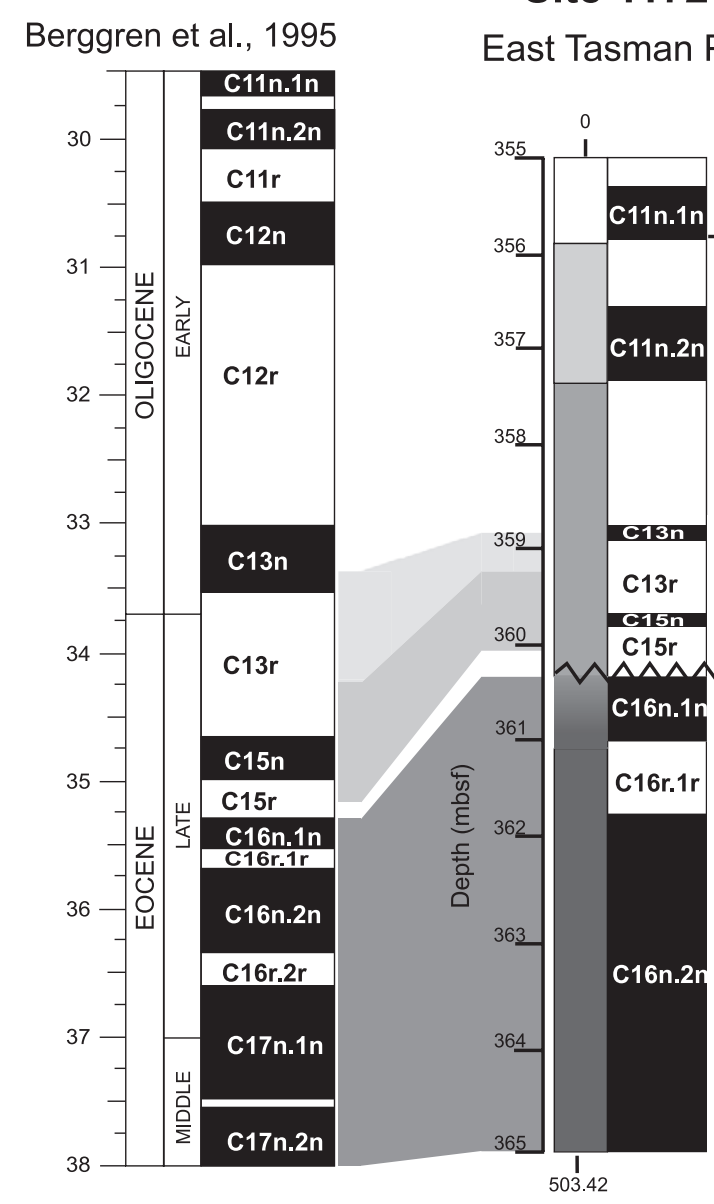

Nannofossil ooze

Nannofossil bearing greenish-gray clayey siltstone

Green glauconite-rich silt- and sandstone

Greyish-brown organic-rich mudstone

\section{Site 1170}

Site 1171

373 South Tasman Rise

Fig. 4. Dinocyst assemblage distribution across the Eocene-Oligocene transition in ODP Leg 189 Sites $1170-1172$ off Tasmania, southwestern Pacific Ocean. Coinciding with accelerated subsidence in the latest Eocene, the Deflandrea- and Phthanoperidinium-dominated assemblages of the early Paleogene are replaced by representatives of Brigantedinium. Based on the results of a multi-proxy approach, this assemblage change has been interpreted to reflect a shift from an environment characterized by runoff-related nutrient supply towards the establishment of an upwelling system. Modified from Sluijs et al. (2003).

(1) Dinocyst association dominated by Deflandrea and Phthanoperidinium

(2) Transitional association

(3) Dinocyst association dominated by Brigantedinium

B Barren of dinocysts 
disciplinary (i.e., multi-proxy) approach. Early Paleogene dinocyst assemblages in sediments from Ocean Drilling Program Leg 189 around Tasmania (South Tasman Rise, East Tasman Plateau) often consist of peridinioid cysts, indicating very high trophic levels (Brinkhuis et al., 2003b; Sluijs et al., 2003). This situation prevailed into the latest Eocene when rapid subsidence of the Tasmanian Gateway initiated (Stickley et al., in press). Coinciding with this deepening is a changeover from assemblages dominated by Deflandrea, Vozzhennikovia and Phthanoperidinium, to assemblages dominated by representatives of Brigantedinium (Fig. 4). The integrated multi-proxy (lithological, geochemical, grain size and diatom) data indicate that e.g., Deflandrea and Phthanoperidinium cysts were representing relatively shallow marine heterotrophic dinoflagellates that were in this case closely tied to an ancient deltaic setting and organic-rich facies (see Brinkhuis et al., 2003a,b; Sluijs et al., 2003, Röhl et al., in press-b for further discussion). Blooms of Brigantedinium, an extant protoperidinioid genus, are wellknown from upwelling regions (Rochon et al., 1999; Reichart and Brinkhuis, 2003) and their motile stage feed on diatoms. Based on the above information, Sluijs et al. (2003) interpreted the latest Eocene assemblage change in the Tasmanian region to reflect a shift from an environment characterized by runoff-related nutrient supply towards the establishment of an upwelling system. Alternatively, the Brigantedinium blooms may reflect sea ice conditions, similar to the situation in modern high latitude oceans (e.g., Wall et al., 1977; Dale and Fjellså, 1994; Rochon et al., 1999).

\subsection{Open-ocean surface productivity}

Variations in organic matter content of sediments are widely considered to be a good proxy for primary productivity (e.g., Suess, 1980; Emerson and Hedges, 1988). In open ocean settings with generally low sedimentation rates, oxidation of organic matter is often intensive. Because dinocysts are among the most resistant organic particles and also represent important primary producers in the upper water column, they can potentially provide a good record of surface productivity in oceanic environments if they are preserved.
However, to date, there have been only few attempts to reconstruct open-ocean surface productivity changes in the Paleogene based on dinocysts. Blooms of Thalassiphora pelagica in upper Eocene hemipelagic and pelagic sediments from central Italy have been ascribed to a marked productivity increase and/or cooling of surface waters, possibly triggered by meteor impacts and related feedback mechanisms (Vonhof et al., 2000; Coccioni et al., 2000). This interpretation is corroborated by $\delta^{13} \mathrm{C}$ data from the sections studied (Vonhof et al., 2000).

\section{Sea surface temperature trends}

Sea surface temperature (SST) is widely considered to be the most important parameter for describing environmental conditions of past oceans and is a crucial factor in paleoclimate modelling (e.g., Wefer et al., 1999). To date, paleo-SST estimations are mostly derived from stable oxygen isotope and magnesium/calcium analysis on calcareous microfossils, and/or quantitative analysis of the latter. The applicability of this approach to high-latitude and sub-calcite compensation depth settings, however, is often hindered by carbonate dissolution. Moreover, calcareous microfossils are usually rare in sediments formed in neritic settings. In this context, dinocysts provide an interesting avenue for SST reconstructions. They are resistant to chemical dissolution and reach high abundances in proximal and distal settings. As in any other group of microorganisms, temperature has a strong control on their growth rate and thus plays an important role in the distribution of dinoflagellate species (de Vernal et al., 1994). Mounting evidence also indicates that dinoflagellates are particularly sensitive to temperature changes compared to other microfossils, making them an excellent tool for SST reconstructions (de Vernal et al., 1993, 1994, 1998, 2000, 2001; Versteegh, 1994; Versteegh and Zonneveld, 1994; Rochon et al., 1998; Grøsfjeld et al., 1999; Devillers and de Vernal, 2000; Boessenkool et al., 2001; Sangiorgi et al., 2002, 2003). Consequently, both quantitative (including transfer-function) and qualitative approaches have been developed to evaluate SST signals in present-day and fossil Quaternary dinocyst assemblages. 
Various Paleogene dinocyst assemblage studies have used qualitative cyst information to infer paleoSST trends. They are based on an empirical and/or statistical differentiation of dinocysts into warm-water, temperate and cold-water elements. Changes in the abundances of the respective elements are then interpreted in terms of a temperature signal.

The approach of evaluating the relative contributions of high/mid-latitude (i.e., cool to temperate) versus low-latitude (i.e., warm) water taxa was originally developed to detect SST variations in the late Eocene and early Oligocene of central Italy (Brinkhuis and Biffi, 1993). It has subsequently been applied to other Paleogene dinocyst records, such as the Oligocene of central Italy (Brinkhuis, 1994), and the early Paleogene of the Southern Ocean (Crouch, 2001; Brinkhuis et al., 2003a,b; Sluijs et al., 2003; Huber et al., in press). It has also yielded reconstructions of SST trends across the CretaceousPaleogene (K/P) boundary section at El Kef, Tunisia, at that time located in the western Tethys, and other $\mathrm{K} / \mathrm{P}$ boundary sections, including Boreal sites (Brinkhuis et al., 1998; Galeotti et al., 2004). To infer paleo-temperature trends for the $\mathrm{K} / \mathrm{P}$ interval, Brinkhuis et al. (1998) followed three interrelated approaches. Detrended correspondence analysis was used to identify SST-related environmental changes and to identify temperature-sensitive species. At the same time, the apparent latitudinal preference of taxa were identified based on literature data. For example, Palynodinium grallator and Membranilarnacia polycladiata represent typical high-latitude taxa, whereas Senegalinium bicavatum is recorded in low latitudes. This enabled the authors to assess the relative contribution of high/mid-latitude versus low-latitude/Tethyan taxa and to evaluate the distribution pattern of rare taxa with very clear latitudinal preferences. Recent analysis and integration of benthic foraminifer and dinocyst records from the El Kef K/ $\mathrm{P}$ boundary indicated an influx of taxa from high/ mid-latitudes, marking a short-term $(\sim 0.5 \mathrm{kyr})$ cooling pulse at the K/P boundary (Fig. 5; Galeotti et al., 2004). This was followed by an episode of pronounced warming that was in turn followed by two more cool-warm cycles before relatively stable warm conditions were reestablished. Galeotti et al. (2004) discuss simulations with fully coupled threedimensional climate models (e.g., Huber and Sloan,
2001), in which incoming solar radiation was reduced to nearly zero, caused by the sulfate aerosols generated by the K/P bolide impact ('impact winter'; e.g., Pope et al., 1997). These simulations show that subsequent cooling of both surface and deeper waters resulted in profound changes in ocean circulation. Both theory and the field observations at El Kef (dinocyst and foraminiferal species from high/ mid-latitudes) indicate the invasion of watermasses with a distinct Atlantic signature into the western Tethys as a direct result of the impact winter (Galeotti et al., 2004).

Shifts in the large-scale distribution of temperaturesensitive cyst-forming dinoflagellates are also documented for the PETM (Bujak and Brinkhuis, 1998; Crouch et al., 2001, 2003a). This brief (ca. 220 kyr) episode at ca. $55 \mathrm{Ma}$ is marked by profound global warming, a major negative carbon isotope excursion (CIE) recorded in the terrestrial and marine realm, and dramatic biotic response (e.g., Kennett and Stott, 1991; Koch et al., 1992; Thomas and Shackleton, 1996; Norris and Röhl, 1999; Zachos et al., 2001, 2003; Bowen et al., 2002). With regard to the dinocyst record, the PETM shows a global acme of the tropical genus Apectodinium in the mid- to high latitudes of both hemispheres that is synchronous with the CIE (Fig. 3; Crouch, 2001; Crouch et al., 2001). Global dinocyst acmes have not been recorded from any other time period, which indicates the intensity of this event. Apparently, PETM warming and accompanying changes in nutrient availability enabled Apectodinium to dominate mid and high latitudes, while many cooler-water dinocyst taxa were reduced. By the end of the PETM, declining temperatures caused the end of the bloom Apectodinium-producing dinoflagellates in mid- and high latitudes and vacant niches were filled by newly evolving taxa (Bujak and Brinkhuis, 1998).

Another large-scale migration of temperature-sensitive dinocysts has recently been documented from the mid Oligocene. Species of the genus Svalbardella are mainly known from the upper Eocene and lower Oligocene of Spitsbergen (Manum, 1960), the Norwegian-Greenland Sea (Manum et al., 1989; Poulsen et al., 1996), the Labrador Sea (Head and Norris, 1989) and off western Tasmania (Brinkhuis et al., 2003a). Hence, its geographical distribution suggest that Svalbardella is a representative of cold-water 


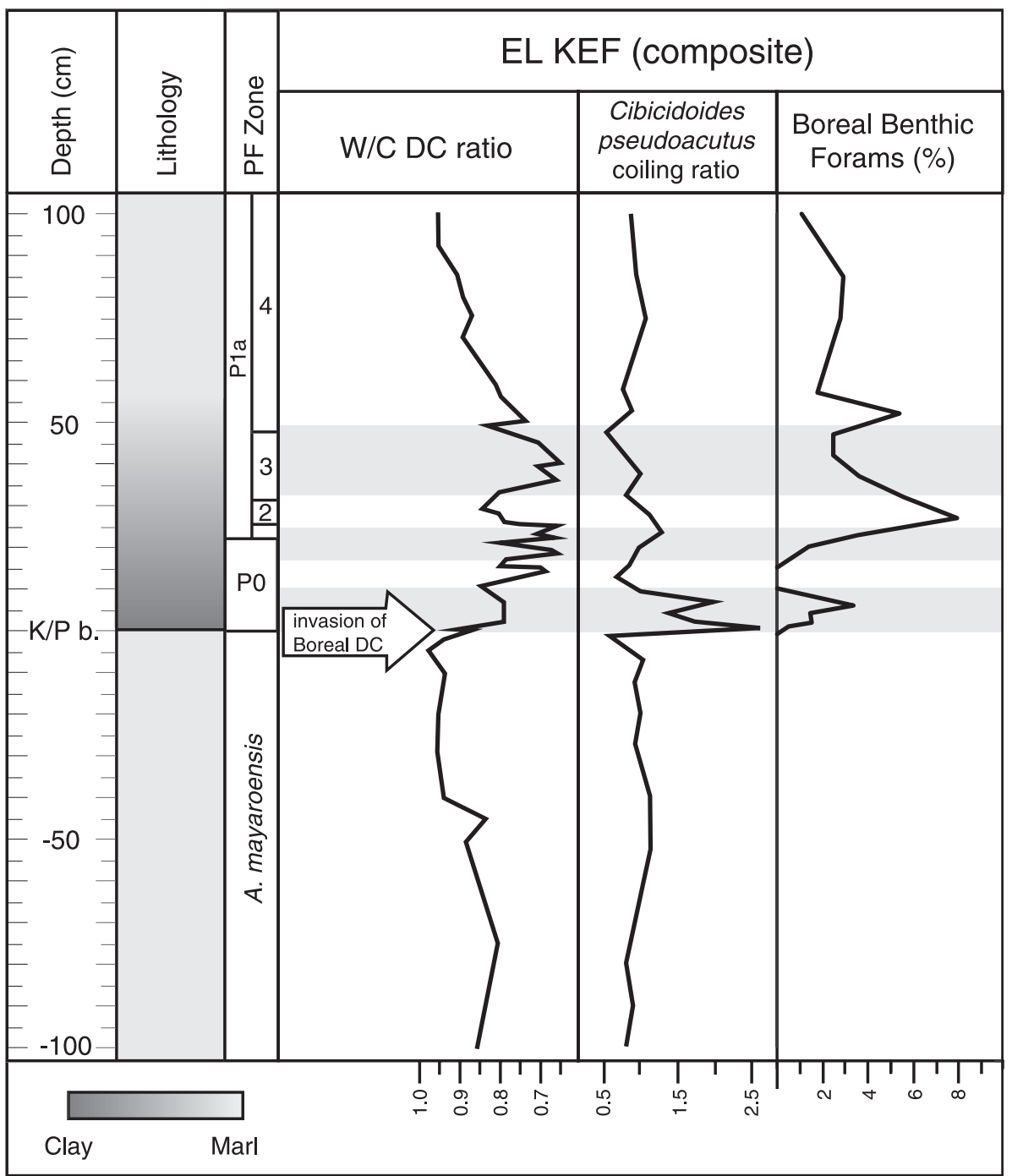

Fig. 5. Dinoflagellate cyst (DC) and benthic foraminiferal records across K/P boundary of El Kef (W/C=warm/cold). Cooler intervals recognized in dinocyst assemblages (shaded bands) coincide with the invasion of boreal benthic foraminifera, and a shift in coiling ratio of benthic foraminifera Cibicidoides pseudoaucutus (indicating a bioprovincial reorganization and/or a temperature change). Galeotti et al. (2004) postulate that this cooling pulse was associated with a distinct Atlantic watermass invading the western Tethyan Realm after the K/P boundary bolide impact. Modified from Galeotti et al. (2004).

environments (Head and Norris, 1989; Brinkhuis et al., 2003a). Dinocyst distribution patterns in several mid- and low-latitude sections in both hemispheres show that representatives of this genus are conspicuously present (up to $10 \%$ of the total dinocyst assemblages) in a distinct interval correlative to the upper part of magnetosubchron C9n (Fig. 6; van Simaeys et al., submitted for publication). The inter- polation between horizons of magnetostratigraphic polarity changes allows the occurrence of this cold water taxon to be constrained to an interval from $\sim 27.65$ to $\sim 27.15 \mathrm{Ma}$ and a duration of $\sim 500 \mathrm{ka}$. The timing of this Svalbardella event coincides with one of the major benthic foraminiferal $\delta^{18} \mathrm{O}$ cooling events near the top of magnetochron C9n known as the Oi-2b event (Miller et al., 1991, 1998; Fig. 6). The 


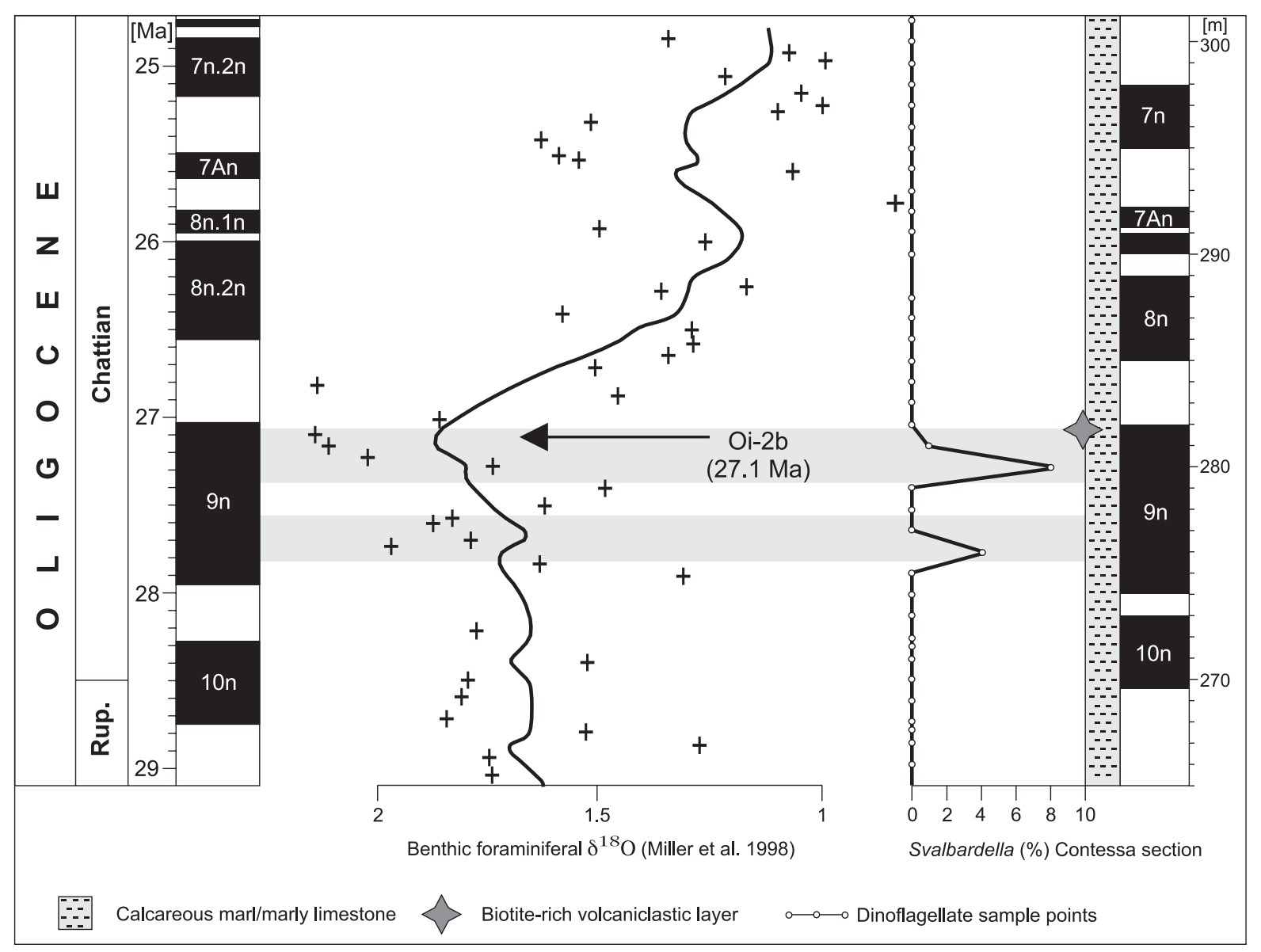

Fig. 6. Distribution of the genus Svalbardella in upper Oligocene sediments from the Contessa section, central Italy. The occurrence of this coldwater taxon is synchronous with a major benthic foraminiferal $\delta^{18} \mathrm{O}$ maximum (Oi-2b event) near the top of magnetochron C9n. The globally synchronous Svalbardella abundance in the upper part of magnetochron C9n coincides with the Oi-2b event, and has been interpreted to indicate distinct atmospheric global cooling and concomitant Antarctic ice-sheet growth. Modified from van Simaeys et al. (submitted for publication).

concomitant occurrence of the global Svalbardella event with the Oi-2b event favours a scenario of distinct surface water and atmospheric cooling in both hemispheres and concomitant Antarctic ice-sheet growth during that time (van Simaeys et al., submitted for publication).

Another example from the Eocene involves the spatial distribution of the Antarctic-endemic (and bipolar) dinocyst assemblage, the so-called 'Transantarctic Flora' (Wrenn and Beckmann, 1982). This assemblage has been widely recognized at sites with a paleolatitude south of $\sim 60^{\circ} \mathrm{S}$ and can be readily distinguished from assemblages with more cosmopolitan or tropical affinities (e.g., Lentin and Wil- liams, 1976; Wrenn and Hart, 1988; Brinkhuis et al., 2003a,b; Sluijs et al., 2003, and references therein). Recently, Brinkhuis et al. (2002b, 2003c) and Huber et al. (in press) modeled the distribution of the Transantarctic Flora in the Australo-Antarctic realm using a fully coupled general circulation model (GCM). Given their newly reconstructed surface circulation, they defined a threshold temperature value of $5{ }^{\circ} \mathrm{C}$ below which cosmopolitan species would not thrive and only members of the Antarctic-endemic assemblage would occur. Brinkhuis et al. (2002b, 2003c) and Huber et al. (in press) showed that the modeled biogeographical distribution of the Transantarctic Flora mirrors the 

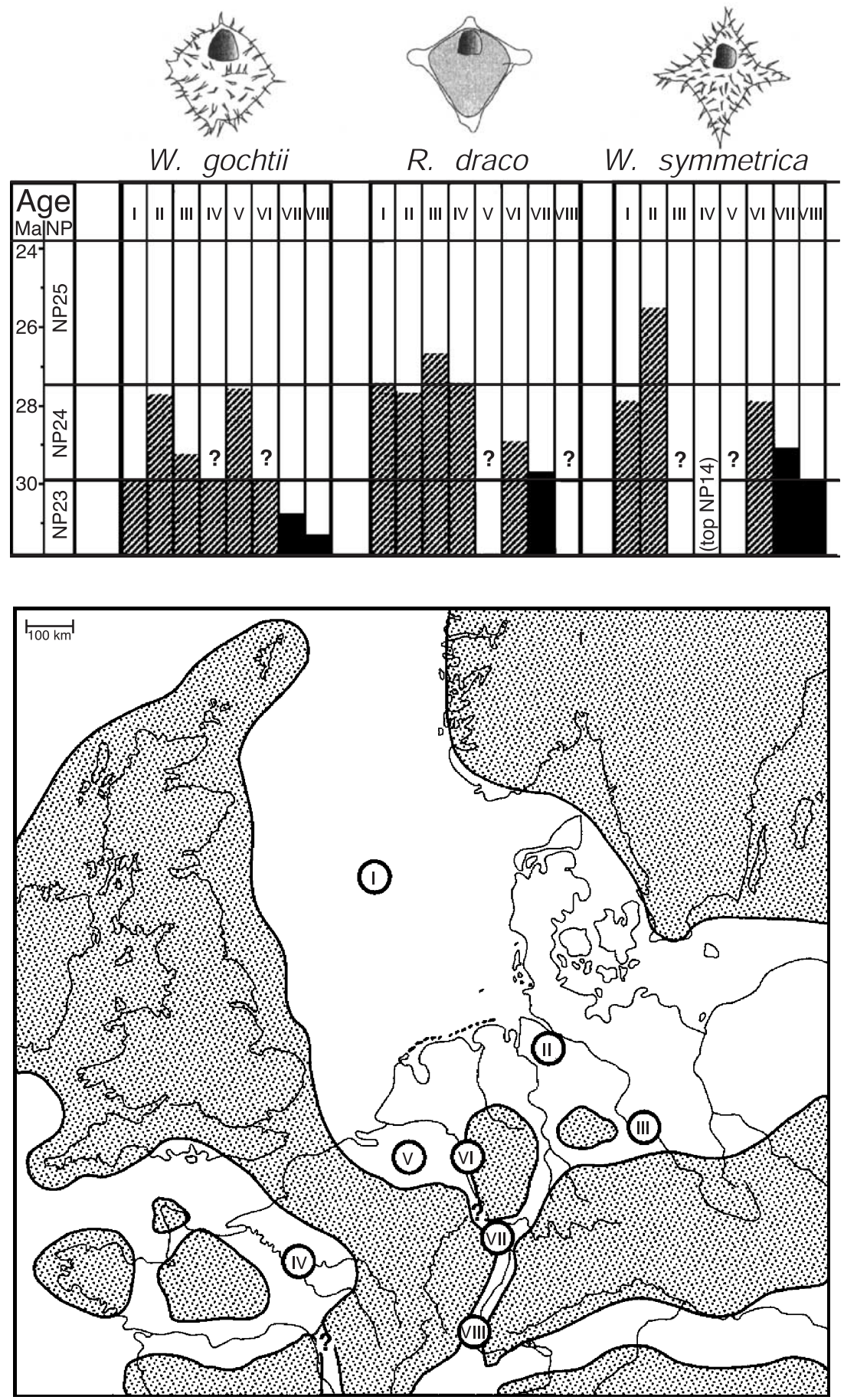

Fig. 7. Early Oligocene paleogeography of northwestern Europe and associated patterns in last occurrences for the species Wetzeliella gochtii, Rhombodinium draco and Wetzeliella symmetrica. Modified from Pross (2001a). 
field observations. Hence, they concluded that the spatial distribution of the Eocene 'Transantarctic dinocyst Flora' was restricted to relatively low temperatures and the nature of Southern Ocean watermass distribution and circulation.

Recently, a significant warming event termed 'the middle Eocene Climatic Optimum' (or MECO; Bohaty and Zachos, 2003) was identified by stable oxygen isotope studies in the late middle Eocene of the Southern Ocean, including Site 748 on Kerguelen Plateau. The pelagic carbonate deposits from this location contain high concentrations of well preserved dinocysts (HB, AS, pers. obs.), which is unusual for deep marine settings. Preliminary results indicate strong assemblage variations across the MECO, with acmes of various cosmopolitan species and declining numbers of representatives of the 'Transantarctic Flora'.

On a more regional scale, Pross (2001a) investigated the spatial distribution patterns of the peridinioid taxa Wetzeliella gochtii, Wetzeliella symmetrica and Rhombodinium draco in the Oligocene of western and northwestern Europe. The last occurrences (LOs) of these taxa proved to be diachronous, with localities from the Northwest European Tertiary Basin exhibiting younger LOs than the southernmost localities (Fig. 7). The maximum time differences are $\sim 4.5 \mathrm{Ma}$ in $W$. symmetrica, $\sim 3.6 \mathrm{Ma}$ in $W$. gochtii and $\sim 3 \mathrm{Ma}$ in $R$. draco. Because these differences seem too large to be explained by dating inconsistencies and because other dinocyst taxa, such as Phthanoperidinium amoenum and $P$. comatum, have isochronous LOs with regard to nannoplankton ages, the LO diachronism was argued to represent a real phenomenon. Pross (2001a) explains this phenomenon by paleoceanographic changes within the gateway connecting the Northwest European Tertiary Basin and the Tethys via the Rhône and Upper Rhine Grabens. An influx from the South of possibly less nutrient-rich, less or more saline, or warmer water masses (or a combination of these factors) may have led to an earlier and stronger environmental deterioration for $W$. gochtii, W. symmetrica and R. draco at the southernmost localities. In contrast, dinocyst assemblages in the Northwest European Tertiary Basin were not affected by this environmental change until later and to a lesser extent, therefore exhibiting the youngest LOs of these species. Similar studies involving diachronous FOs and
LOs of Eocene dinocyst have been successfully related to progressive changes in SSTs in the North Sea Basin and the NE Atlantic (J.P. Bujak, pers. comm.).

In summary, the SST control over the Paleogene spatial dinocyst distribution has become well established. To date, dinocyst-based SST reconstructions are shown to be especially important for higherlatitude and neritic environments, where the application of approaches based on calcareous microfossils is often problematic.

\section{Salinity trends}

Salinity, together with temperature, determines the density of water masses and thus represents an important component controlling thermohaline circulation. To date, methods for determining paleo-salinity have predominantly utilized oxygen isotopes and ecological preferences of foraminiferal assemblages (see Wolff et al., 1999 for a detailed discussion). As salinity is a prime factor controlling osmotic exchanges in microorganisms, it also plays a role in the distribution of dinoflagellates (e.g., de Vernal et al., 1994). Salinity levels may also affect the cyst morphology of dinoflagellate species (Wall et al., 1973; Wall and Dale, 1974; Lewis et al., 1999, 2003). This may result in multiple cyst-based taxa for one theca-based species.

Morphological changes in dinocysts as a result of low salinity or other environmental stress were first described by Wall et al. (1973) and Wall and Dale (1974) based on Holocene material from the Black Sea. They observed that in low-salinity environments as compared to normal-salinity assemblages an increased number of dinocysts with reduced processes, variations in septal development and a cruciform rather than a rounded endocyst. Moreover, changes in archeopyle formation have also been attributed to salinity fluctuations (Wall et al., 1977). The hypothesis that salinity was a factor in determining process length in various chorate dinocysts has been corroborated by recent studies on Lingulodinium machaerophorum/L. polyedrum (e.g., Nehring, 1994a,b), Operculodinium centrocarpum (e.g., de Vernal et al., 1989; Matthiessen and Brenner, 1996) and Spiniferites spp. (e.g., Dale, 1996; Ellegaard, 2000; Lewis et al., 1999, 2003). The suggestion that a cruciform endo- 
cyst may indicate the influence of a low-salinity environment has also been corroborated by Dale (1996) and a recent study on cruciform Spiniferites cysts from a lacustrine setting in northern Greece (Kouli et al., 2001). Taking these hypotheses a step further, Brenner (2001) used process length variations in $O$. centrocarpum to reconstruct Holocene salinity changes in the Baltic Sea.

In terms of cyst formation, the morphological changes are probably related to an early rupture of the outer membrane surrounding the dinoflagellate theca and cyst (Kokinos and Anderson, 1995). Laboratory findings, however, indicate a more complex relationship between cyst morphology and salinity. Although it has been shown that the process lengths in Lingulodinium machaerophorum are reduced at low salinities (Lewis and Hallet, 1997), monoclonal cultures of this taxon can develop different process lengths even under stable salinity conditions (Kokinos and Anderson, 1995). Similarly, the development of different morphotypes in Spiniferites membranaceus and $S$. ramosus also occurs under stable salinity (Lewis et al., 1999). Hence, salinity is probably not the only factor controlling these morphological changes and other parameters of environmental stress may also be involved. These findings are supported by a study on late Quaternary dinocysts from the Black, Marmara and Aegean Seas (Mudie et al., 2001). For L. machaerophorum, there emerged no clear statistical relationship $(R=0.33)$ between process length and salinity as inferred from the foraminiferal signal. Moreover, there was a weak inverse correlation between salinity and relative abundance of Spiniferites cruciformis $(R=-0.61)$ and also between salinity and the percentages of a specific morphotype of $S$. cruciformis $(R=-0.67)$, with the degree of velum development decreasing with lowered salinity. Other S. cruciformis morphotypes did not correlate with salinity. Kouli et al. (2001) recorded S. cruciformis together with the freshwater species Gonyaulax apiculata in lacustrine sediments. They suggest that $S$. cruciformis is a freshwater species and that any occurrences in (brackish) marine environments, with the exception of specimens with strongly reduced ornamentation, may be due to transportation, short-lived freshwater surface conditions and/or tolerance of the species to brackish conditions. Mudie et al. (2002), using material from the Marmara and Black seas, followed an actuopaleontological approach towards a paleosalinity quantification. Their data are compatible with Kouli et al. (2001) as they show S. cruciformis to co-occur with taxa found in freshwater environments and also use $S$. cruciformis to reconstruct brackish water environments ( $\sim 7-18$ practical salinity units) and freshwater input from glacial lakes.

Among Paleogene and Neogene dinocyst taxa, members of the Homotryblium complex (i.e., many taxa of the family Goniodomaceae such as Eocladopyxis, Heteraulacacysta, Polysphaeridium; see Fensome et al., 1993) are widely considered to be characteristic of restricted settings with increased salinity (see Brinkhuis, 1994 for a detailed discussion). This attribution is due to morphological similarities with the extant high-salinity indicator Polysphaeridium zoharyi and the group's empirically derived preference for low- to mid-latitude, inner neritic environments (Reichart et al., 2004). In a study on early Oligocene dinocysts from a neritic setting in southern Germany, Pross and Schmiedl (2002) interpreted alternating intervals dominated by Homotryblium tenuispinosum/H. floripes and Thalassiphora pelagica, respectively, to indicate alternations between high- and low-salinity conditions. This distribution pattern was explained through a model invoking repeated environmental changes from relatively dry to relatively humid conditions and stratification (Fig. 8). High abundances of H. tenuispinosum and $H$. floripes reflected drier periods where reduced runoff, in combination with strong evaporation, led to increased salinity in nearshore settings. Periods of maximum runoff were indicated by high abundances of $T$. pelagica, interpreted to reflect reduced salinity in the surface waters, increased productivity, salinity stratification and resulting oxygen depletion in the deeper water column (Fig. 8). Similarly, Köthe (1990) interpreted intervals of high Homotryblium abundances in the Oligocene and Miocene of northwest Germany to indicate high-salinity conditions.

Acmes of Homotryblium tenuispinosum have also been recorded alongside high abundances of the freshwater algae Pediastrum spp. which indicates a brackish setting (S. van Simaeys, pers. comm., 2003). Its co-occurrence with Pediastrum implies that the Homotryblium motile cell was tolerant of a wide range 

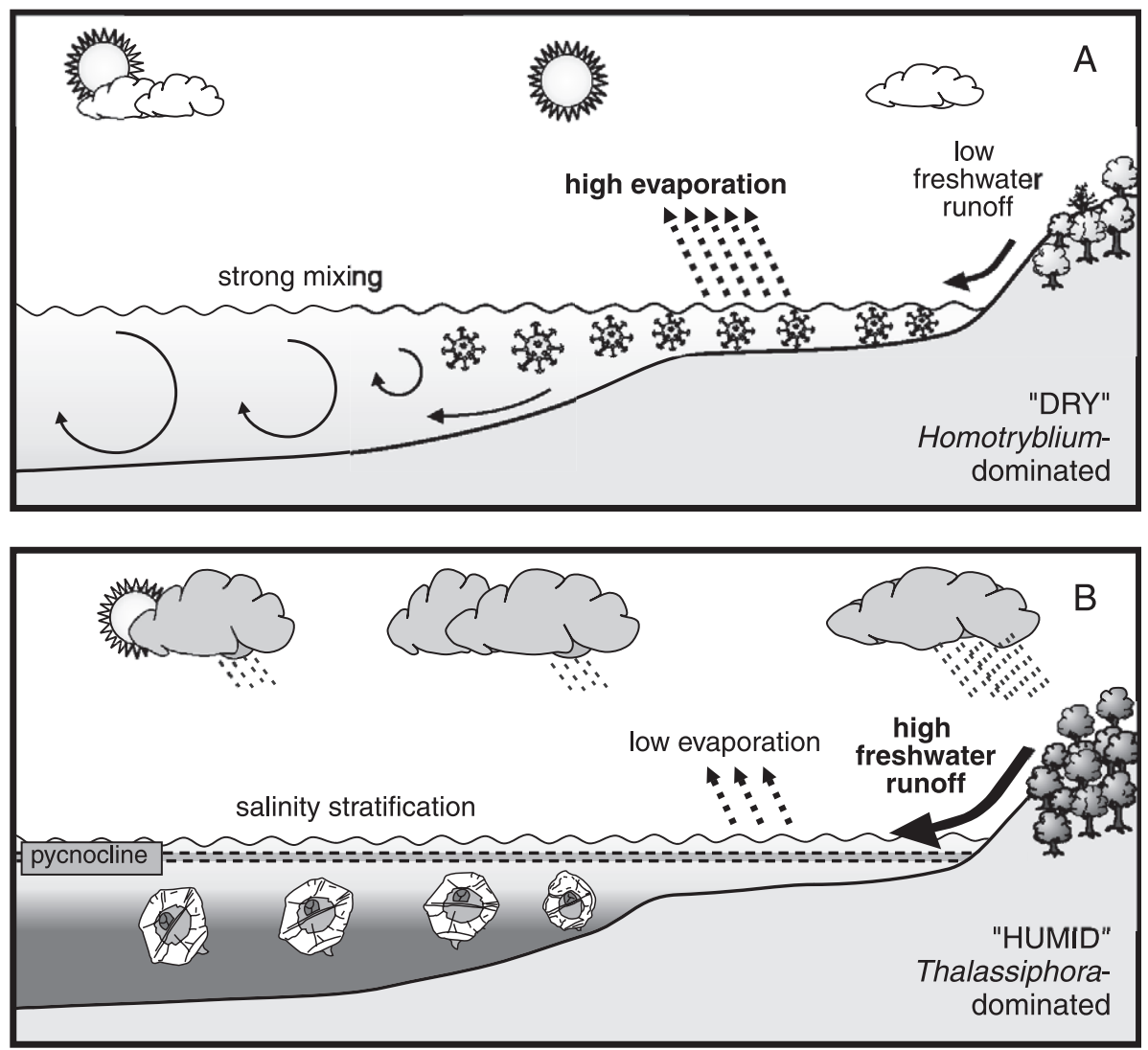

Fig. 8. Schematic model for the response of cyst-forming dinoflagellate populations to climate-induced oceanographic changes in the lower Oligocene of southern Germany. (A) During relatively dry periods (dominance of Homotryblium tenuispinosum), reduced runoff and strong evaporation caused high sea surface salinity. (B) During relatively humid periods (dominance of Thalassiphora pelagica) high freshwater discharge lead to increased nutrient input, salinity stratification and a decrease in bottom water oxygenation. See text for further explanation. Modified from Pross and Schmiedl (2002).

of salinities, similar to extant Pyrodinium bahamense (the thecal stage of the dinocyst $P$. zoharyii).

Based on the aforementioned studies, the analysis of the distribution pattern of Homotryblium and allied genera can yield information on salinity conditions in the Paleogene. Although most available records suggest an affinity of Homotryblium to hypersaline environments, there are indications that the genus may also have favoured abnormally lowsalinity conditions. Because Homotryblium first occurs in the early Paleocene (Iakovleva et al., 2001) and has a last occurrence in the mid-Miocene (Brinkhuis, 1994), it provides a valuable tool in dinocyst-based salinity reconstructions for most of the Paleogene.

\section{Proximal-distal trends}

Due to the general life strategy of organic cystforming dinoflagellates (e.g., commonly involving neritic settings) and the adaptation of many species to specific surface water conditions, marine dinoflagellate assemblages show a strong proximal-distal signal. Hence, the dinocyst assemblages from the sediments can be used to reconstruct the influence of inshore waters in a more offshore locality (Brinkhuis, 1994), despite possible taphonomic problems such as long-distance transport (e.g., Dale and Dale, 1992).

In a pioneering study on the inshore-offshore distribution pattern of modern dinocysts, Wall et al. 
(1977) attributed different cyst taxa to specific locations within neritic to oceanic transects. Their classification is based on the presence or absence of taxa considered to be typical for oceanic settings and on relative changes in species composition from nearshore to offshore. The results of Wall et al. (1977) have been corroborated by many later studies (e.g., Edwards and Andrle, 1992; Dale, 1996) and can be summarized as follows: (1) Oceanic settings are characterized by the occurrence of Impagidinium. The environmental preference of this genus seems so clearly defined that even the occurrence of a few specimens may indicate an oceanic environment (Dale, 1996). Hence, if one assumes that Impagidinium has not changed its ecological preference since it first appeared in the Cretaceous, its occurrence can provide a tool to differentiate distal, oligotrophic settings from other, more proximal environments.

(2) Species of Nematosphaeropsis and Tectatodinium indicate a neritic to oceanic environment; and (3) the occurrence of most other cyst taxa are representative of coastal to neritic settings.

Based on the premise that many dinoflagellate species are adapted to specific surface water conditions and utilizing literature information such as Wall et al. (1977), Brinkhuis (1994) presented a schematic model for the composition of gonyaulacoid (predominantly autotrophic) dinocyst assemblages along a proximal-distal transect as given by Eocene/Oligocene sections in northeast Italy (Fig. 9). $\mathrm{He}$ proposed a sequence of optimum abundances along an inner neritic to outer neritic and finally oceanic transect of the Homotryblium, Areoligeral Glaphyrocysta, Operculodinium, Enneadocysta/Spiniferites, Nematosphaeropsis/Cannosphaeropsis and Impagidinium groups (Fig. 9). This classification scheme has subsequently been applied and modified in other studies on Paleogene dinocysts (e.g., Crouch, 2001; Pross and Schmiedl, 2002; Röhl et al., in press-b). In a multi-proxy study on marginal marine Eocene deposits in the Southern Ocean, Röhl et al. (in press-b) showed that the relative abundance of Enneadocysta spp. positively correlates with the $\mathrm{CaCO}_{3}$ content of the neritic sediment, which suggests a slightly more offshore, less eutrophic setting (Fig. 10). In turn, high abundances of Deflandrea spp., corresponding to more $\mathrm{CaCO}_{3}$-depleted sediments, indicate a more inshore setting. According to
Röhl et al. (in press-b), the dinocyst assemblage and $\mathrm{CaCO}_{3}$ content variations represent astronomically forced, sea-level driven cycles within the Milankovitch bands.

Studies on the distribution pattern of Recent dinocysts have shown that - apart from nutrient availability and water temperature (e.g., Matsuoka, 1992; Dale, 1996) - cyst diversity strongly depends on the stress in ecosystems (e.g., Patten, 1962; Bradford and Wall, 1984). As stress is often related to relative shoreline proximity, the dinocyst diversity signal may thus also be broadly used as an indicator of the latter. This approach has been taken in several Paleogene dinocyst studies. A study on early Oligocene assemblages from an epicontinental basin in Central Europe revealed a rise in mean dinocyst diversity values with increasing distance from the shoreline (Pross and Schmiedl, 2002). Maximum mean values of the Shannon-Wiener information index $H(S)$, which was used to characterize the diversity of dinocyst assemblages, occurred in the center of the basin at a distance of $\sim 15 \mathrm{~km}$ from the paleo-shoreline. Assemblages from more intermediate and proximal settings exhibited consistently decreasing $H(S)$ values. The same picture emerged for the equity index $(E)$, which was used to describe the equity within dinocyst assemblages (Pross and Schmiedl, 2002). Hence, the diversity of dinocyst assemblages can render information on stress, and hence onshore-offshore trends in epicontinental settings.

\subsection{Sequence stratigraphic application}

In view of the above, the composition of dinocyst assemblages and dinocyst diversity can serve as an indicator for watermass composition, which is closely associated with shoreline proximity. Thus, changes in assemblage composition and diversity may be used to determine transgressive-regressive phases and can be related to changes in relative sea level. This has led to the successful application of dinocyst studies in sequence stratigraphy starting with Haq et al. (1987). As noted earlier in this paper, a species diversity plot for Mesozoic to Cenozoic dinocysts shows striking similarities to the general trend of the sea level curve of Haq et al. (1987), with high diversity corresponding to high sea level and vice 


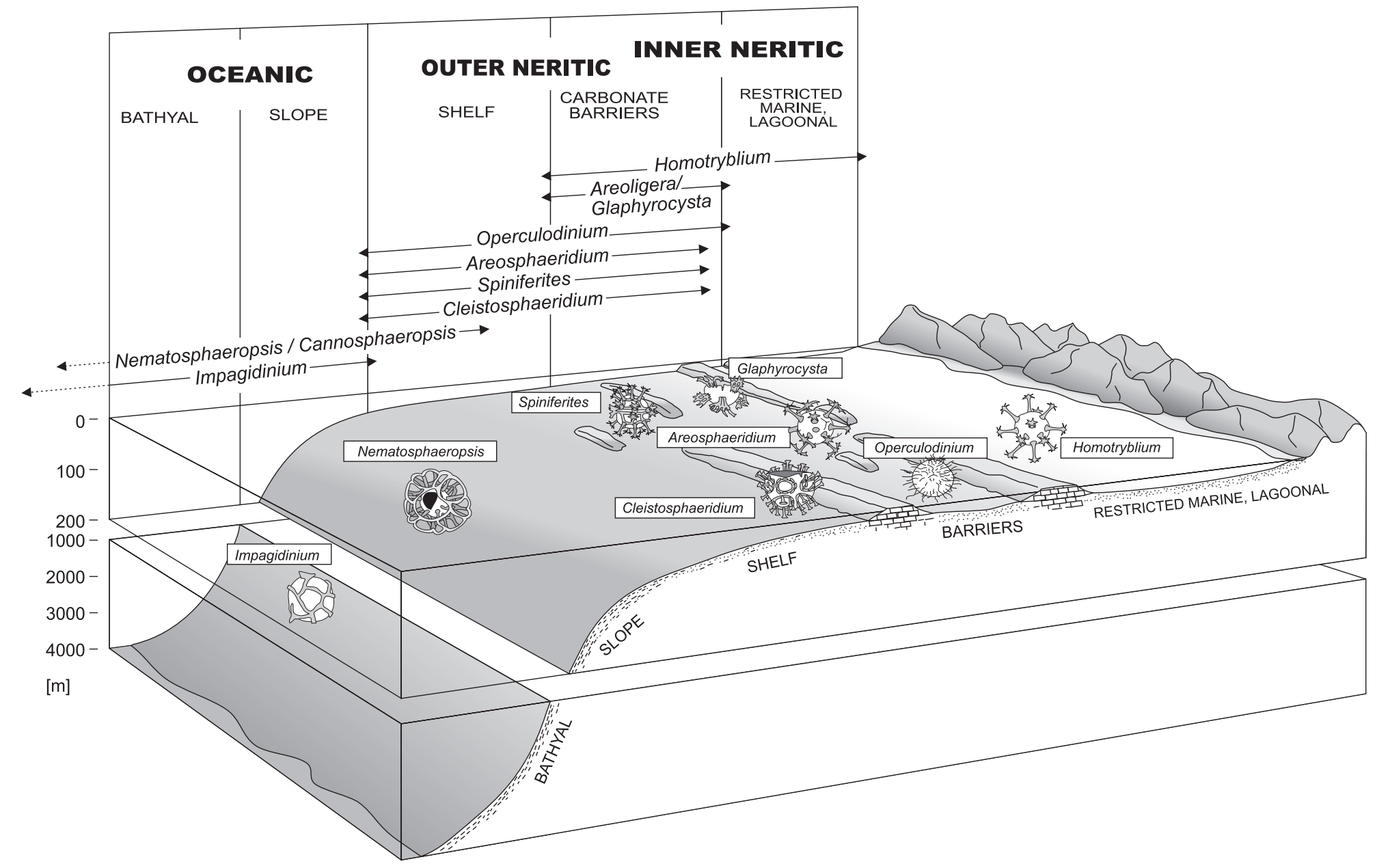

Fig. 9. Schematic model for the distribution of dinocyst associations along a proximal-distal transect during the late-Eocene and early Oligocene in central Italy. Modified from Brinkhuis (1994). 


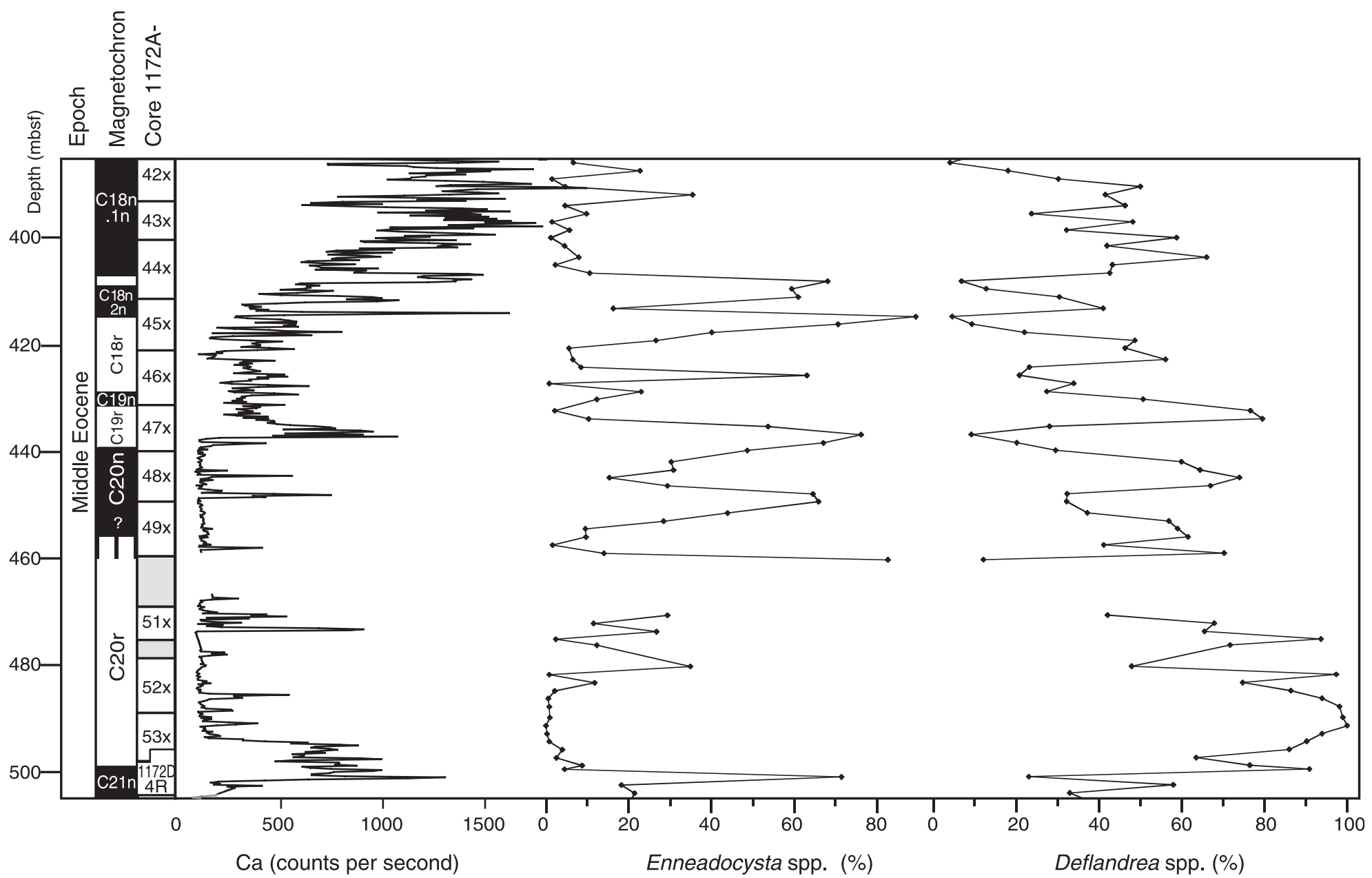

Fig. 10. High-resolution XRF calcium intensity (in counts per second) and the distribution of Deflandrea spp. and Enneadocysta spp. through a middle Eocene interval of ODP 189 Site 1172 in the Tasman Sea. The dinocyst assemblage and $\mathrm{CaCO}_{3}$ content variations are thought to represent astronomically forced, sea-level driven cycles within the Milankovitch bands. Modified from Röhl et al. (in press (b)) 
versa (Fig. 1). Existing dinocyst-based reconstruction of sea-level changes can be subdivided into (1) studies primarily utilizing differences in assemblage composition and (2) studies evaluating the diversity and abundance signal within assemblages.

Based on changes in the composition of dinocyst assemblages, Brinkhuis and Biffi (1993) and Brinkhuis (1994) reconstructed sea-level fluctuations of different magnitudes across the Eocene/Oligocene transition in Italy. An increase of outer neritic to oceanic taxa (such as species of Nematosphaeropsis and Impagidinium) was interpreted to indicate a sea level rise, whereas increasing abundances of neritic to coastal taxa were interpreted to denote a regressive trend. The results indicate a latest Eocene episode of low sea level (correlated to the boundary of the third-order cycles TA4.2 and TA4.3 of Haq et al., 1988) and a pronounced earliest Oligocene sealevel fall (correlated to the TA4.3/4.4 type 1 se- quence boundary of Haq et al., 1988). These major events were accompanied by cooling as reflected by increased abundances of higher-latitude species, which supports the idea of glacio-eustatic control on the late Eocene/Oligocene sea-level curve. Minor fluctuations, in contrast, were not connected to cooling as shown by the dinocyst signal and were interpreted to be the result of local to interregional tectonics (Brinkhuis, 1994). Similarly, Peeters et al. (1998) were able to discriminate between tectonically and eustatically driven sea-level change in the Eocene/Oligocene Pindos Basin, Greece. Powell et al. (1996) developed a dinocyst-based "sequence biostratigraphy" for late Paleocene/early Eocene sections from southeast England. Based on the proximal-distal signals of different dinocyst groups similar to those defined by Brinkhuis (1994) and additional information from other accompanying aquatic palynomorphs, Powell et al. (1996) proposed
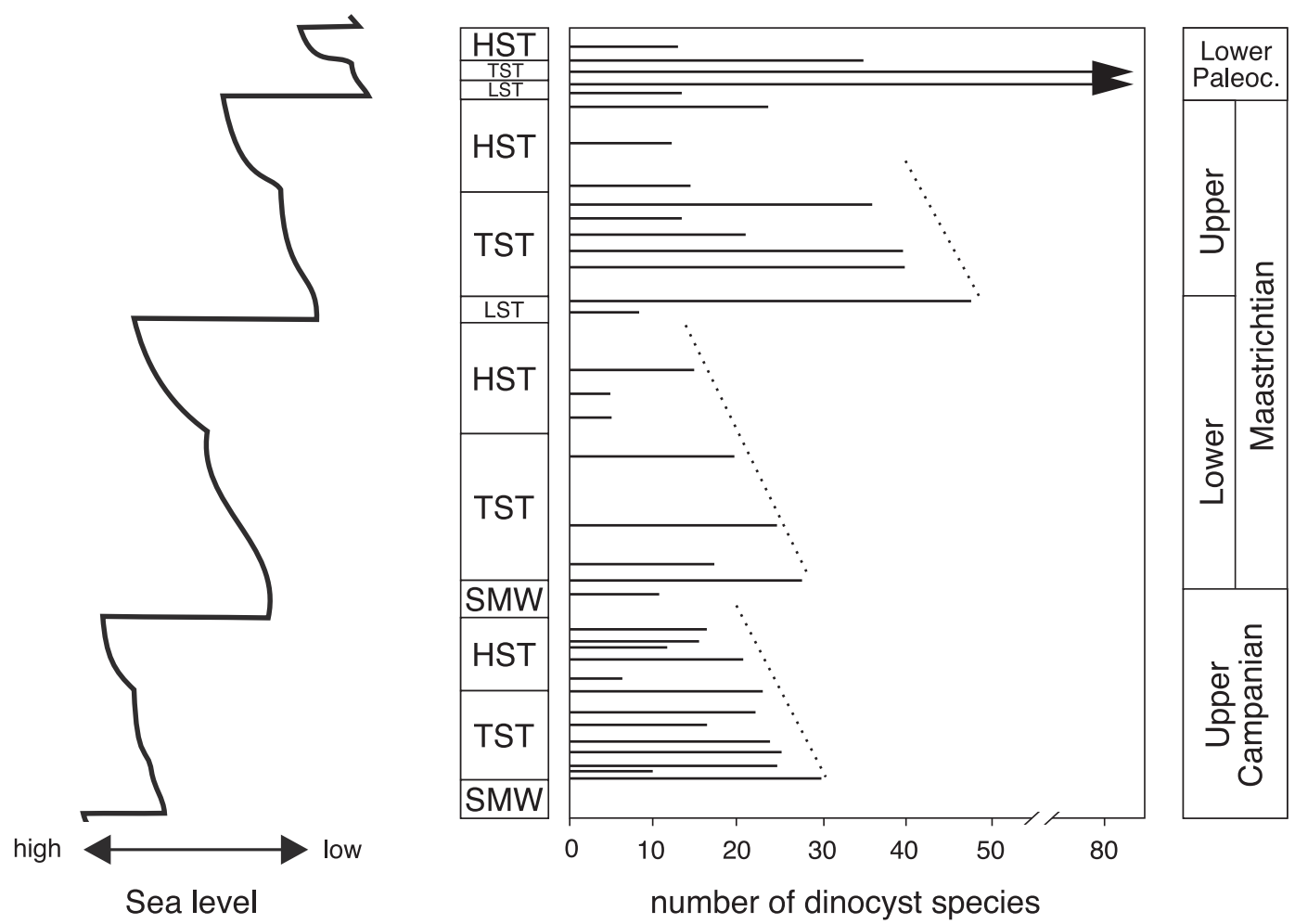

Fig. 11. Dinocyst diversity correlated to the sequence stratigraphy in the upper Cretaceous and lower Paleocene of the southern United States. Diversity maxima occur at the base of the transgressive system tracts (TST), whereas diversity minima fall within the lowstand system tracts (LST). HST= highstand system tract, SMW= shelf margin wedge. Modified from Moshkovitz and Habib (1993). 
eight sequences in the studied sections that could be correlated to the well-established sequence stratigraphy of the North Sea Central Graben. Similar approaches have been taken by Zevenboom et al. (1994), Zevenboom (1996), Wilpshaar et al. (1996), Iakovleva et al. (2001) and Van den berghe et al. (2003).

In a study on the sequence stratigraphic significance of dinocysts in the Lower Oligocene of Belgium, Stover and Hardenbol (1994), took a similar approach and could show that the number of dinocyst species increased rather abruptly in the transgressive systems tract above the underlying sequence boundary. Once established, species numbers remained relatively constant into the early highstand deposition and increasingly deteriorated during late highstand deposition. The majority of dinocyst range bases were positioned in transgressive systems tracts, which can probably be attributed to a widening of shelfal dinoflagellate habitats, fostering the evolution of new dinoflagellate taxa. Accordingly, range tops were predominantly found in highstand systems tracts.

For the upper Cretaceous and lowermost Paleogene of the southern U.S., a similar relationship between dinocyst diversity and sea level change has been postulated (Habib and Miller, 1989; Habib et al., 1992; Moshkovitz and Habib, 1993). Minimum species numbers occurred in lowstand deposits and maximum species numbers were observed at the base of transgressive systems tracts (Fig. 11). The evaluation of dinocyst species numbers to determine sea-level change has been especially useful for establishing a sequence stratigraphic framework for the Cretaceous/Paleogene boundary interval, because dinoflagellates did not undergo a mass extinction as calcareous microfossils (Habib et al., 1992).

In summary, the dinocyst signal shows a strong proximal/distal differentiation as a result of dinoflagellate sensitivity to the wide range of physiochemical characteristics of neritic watermasses along the inshore-offshore transect. Through the formation of benthic resting cysts in most cyst-producing dinoflagellates, there is also a link to water depth. The proximal/distal signal is expressed by changes in assemblage composition, assemblage diversity and cyst abundances. The strong expression of the proximal/distal signal in dinocyst assemblages has led to the successful application of dinocyst studies in sequence stratigraphy.

\section{Stratification}

Most dinoflagellate cysts species are known from shallow marine (i.e., shelfal) settings. This is because dinoflagellates need to be able to return to the photic zone after excystment, which limits the maximum water depth of the habitat and inhibits occurrences of most cyst-forming species in the open ocean. Recently, however, assemblages dominated by the typical restricted marine, lagoonal species Polysphaeridium zoharyi were recorded in Pleistocene open-oceanic sediments from the Arabian Sea (Reichart et al., 2004). P. zoharyi represents the cyst stage of Pyrodinium bahamense, a harmful dinoflagellate known from lagoons that is tolerant of strong salinity fluctuations (see Section 5). Conspicuously, the $P$. zoharyi blooms were recorded in sediments deposited during warm interstadials following strong Heinrich events (Fig. 12). Reichart et al. (2004) postulated that rapid warming in the North Atlantic region immediately following the Heinrich events led to a decrease of the winter monsoon intensity in the Arabian Sea. In turn, this resulted in the interruption of deep mixing that had persisted during glacial times in the Arabian Sea. The weakening of the winter monsoon predated the subsequent strengthening of the summer monsoon and ongoing evaporation resulted in the development of very high sea surface salinity and a shallow and unusually strong pycnocline in the Arabian Sea. Reichart et al. (2004) termed this phenomenon 'hyperstratification' (Fig. 13). The strong pycnocline provided a virtual seafloor, enabling $P$. zoharyi to complete its life cycle prior to sinking into deep water. This 'hyperstratification', in combination with high sea surface salinity, provided optimum living conditions for $P$. zoharyi in open-ocean environments (Reichart et al., in press). Although hyperstratified conditions as described from the Quaternary of the Arabian Sea have not (yet) been identified by dinocysts in the pre-Quaternary, dinocysts with high-salinity affinities such as Homotryblium are well known to dominate lagoonal settings in the Paleogene (see Section 5). 


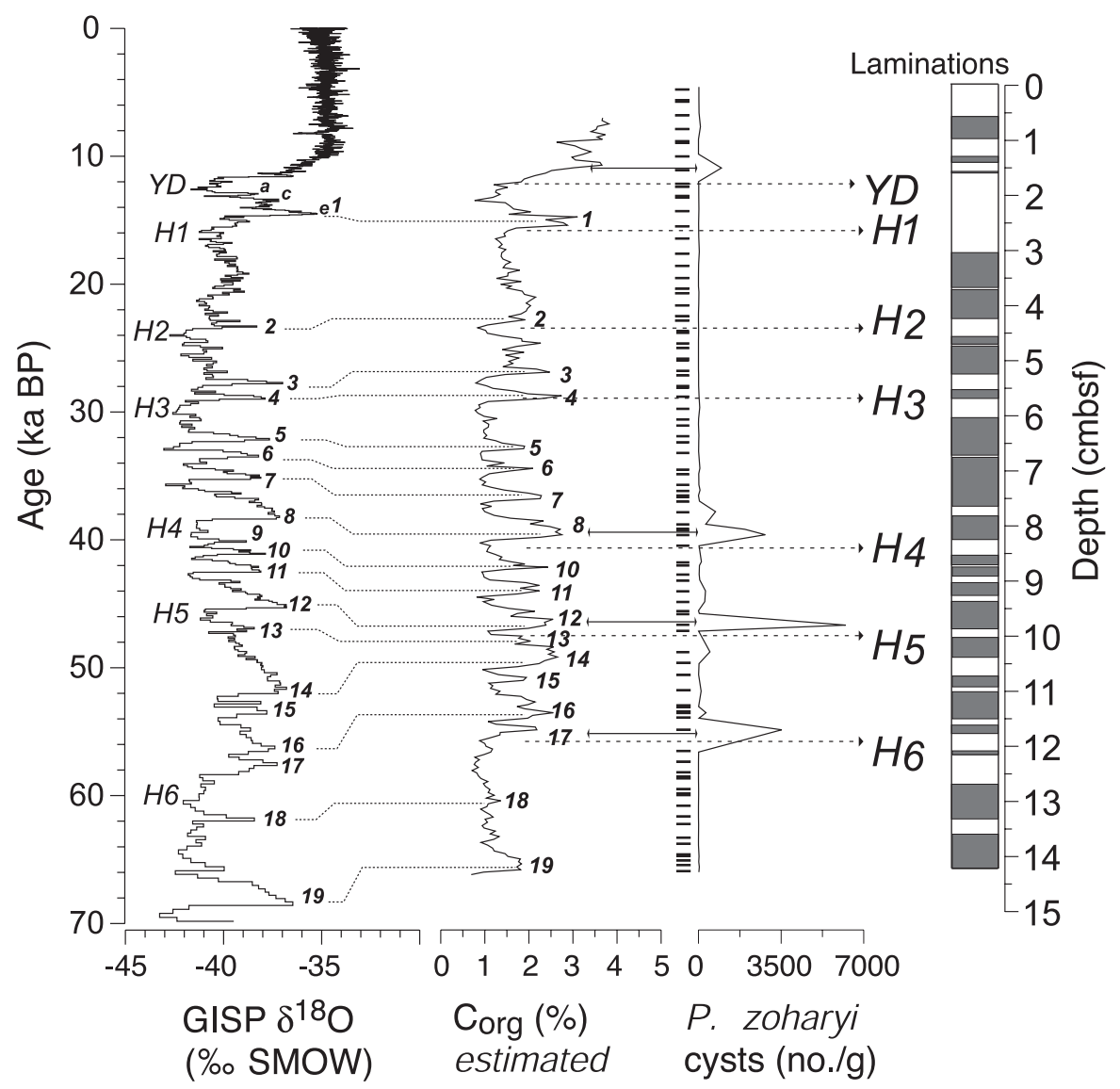

Fig. 12. Correlation between the oxygen isotope record of the GISP2 Greenland ice core, the predicted organic carbon record (see Reichart et al., 2004), and abundance of Polysphaeridium zoharyi cysts. Numbers 1-19 refer to interstadials, H1 - H6 refer to Heinrich events 1-6, YD refers to the Younger Dryas. Laminated intervals are indicated in grey. Position of palynological samples are indicated by thin horizontal lines next to the P. zoharyi record. Solid lines with arrows indicate events characterized by P. zoharyi. Modified from Reichart et al. (2004).

Thus, they have the potential to record hyperstratified open-ocean conditions during this time interval and it is possible that some of the presumed Oligocene deep marine records of abundant Homotryblium may actually represent such processes (e.g., Stover, 1977).

\section{Bottom water and water column oxygenation}

Reconstructing the oxygenation of marine sediments has long been a focus of geologists because of the relevance of low-oxygen conditions in the formation of hydrocarbons. Moreover, oxygen availability is a prime factor in controlling diversity and abundance of, particularly, benthic biota, and it can also provide paleoceanographic, paleogeographic and paleoclimatic information. Consequently, various paleontological, sedimentological and geochemical approaches have been developed to reconstruct the oxygenation of marine sediments (cf. Allison et al., 1995).

Studies on modern dinoflagellates have shown that oxygen availability exerts a strong control on cyst germination, with anaerobic conditions completely inhibiting the excystment of most taxa (Anderson et al., 1987). Because dinocysts in shelf environments typically reach the sea floor before excystment (Dale, 1983) and are therefore exposed to bottom water conditions, cyst assemblages in shelf environments 
Interglacial

\section{a) winter monsoon}

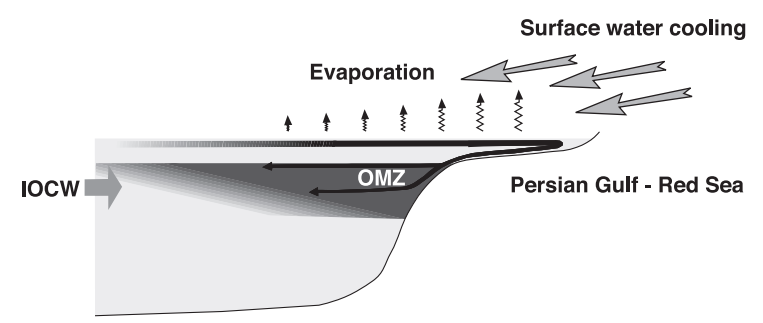

Glacial

b) strong winter monsoon (stadial)

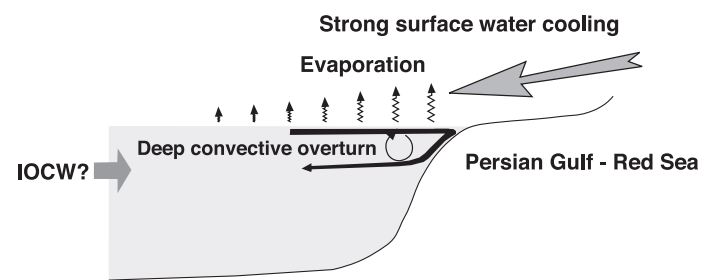

c) weak winter monsoon (interstadial)

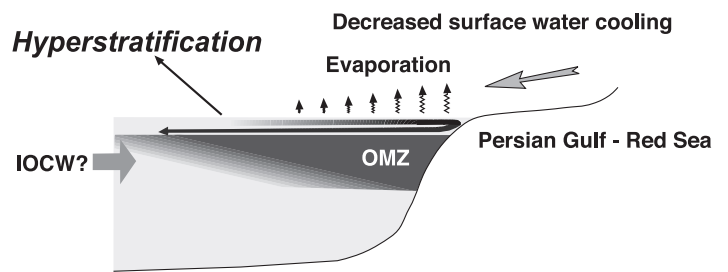

Fig. 13. Schematic representation of surface and intermediate water circulation during interglacial (present) and glacial times in the Arabian Sea. The present-day (a) circulation of the intermediate water is dominated by the inflow of relatively oxygen-poor Indian Ocean Water (IOCW) and inflow at depth of warm and saline water from the Persian Gulf and Red Sea. The two glacial scenarios represent full stadial conditions (b) and the transition from stadial to interstadial (c). The brief periods of hyperstratification at stadial-interstadial transitions are inferred from the Polysphaeridium zoharyi data. Modified from Reichart et al. (2004).

may well bear a benthic oxygenation signal. Although shelves are usually well-ventilated, several studies on fossil dinocyst assemblages from Jurassic, Cretaceous and Paleogene organic-rich shelf sediments have revealed changes that possibly relate to variations in benthic oxygenation. Sediments deposited under low-oxygen conditions showed reduced cyst diversities and shifts within cyst assemblages (Jarvis et al., 1988; Marshall and Batten, 1988; Leckie et al., 1992; Pross, 2001b; Bucefalo-Palliani et al., 2002).

Changes in dinocyst assemblages as a response to oxygen depletion at the sediment surface and in the water column of epeiric settings have been observed in early Oligocene sediments (Pross, 2001b). Dinocyst assemblages from oxygen-depleted intervals within the Mainz Embayment, SW Germany, are characterized not only by reduced dinocyst diversities, but also by high abundances of Thalassiphora pelagica. The relative abundance of this species correlates inversely with the availability of bottomwater oxygen, as inferred from benthic foraminifera, and strong, probably runoff-induced stratification. Apparently, T. pelagica could successfully cope with this set of environmental parameters where others failed. Noting the unusual morphology of T. pelagica and studying its morphological variability quantitatively, Pross (2001b) proposed a model linking all aspects of the phenomenon. T. pelagica is characterized by a wing-like membrane on the dorsal side of most specimens, which may have facilitated a holoplanktic life cycle in contrast to most other cystproducing dinoflagellates. Pross (2001b) interpreted the observed distribution pattern to mirror the effect of bottom-water oxygen depletion on dinoflagellates with a benthic resting cyst stage (Fig. 14). In his model, excystment of these other taxa was inhibited or reduced, leading to a decrease in dinocyst diver- 


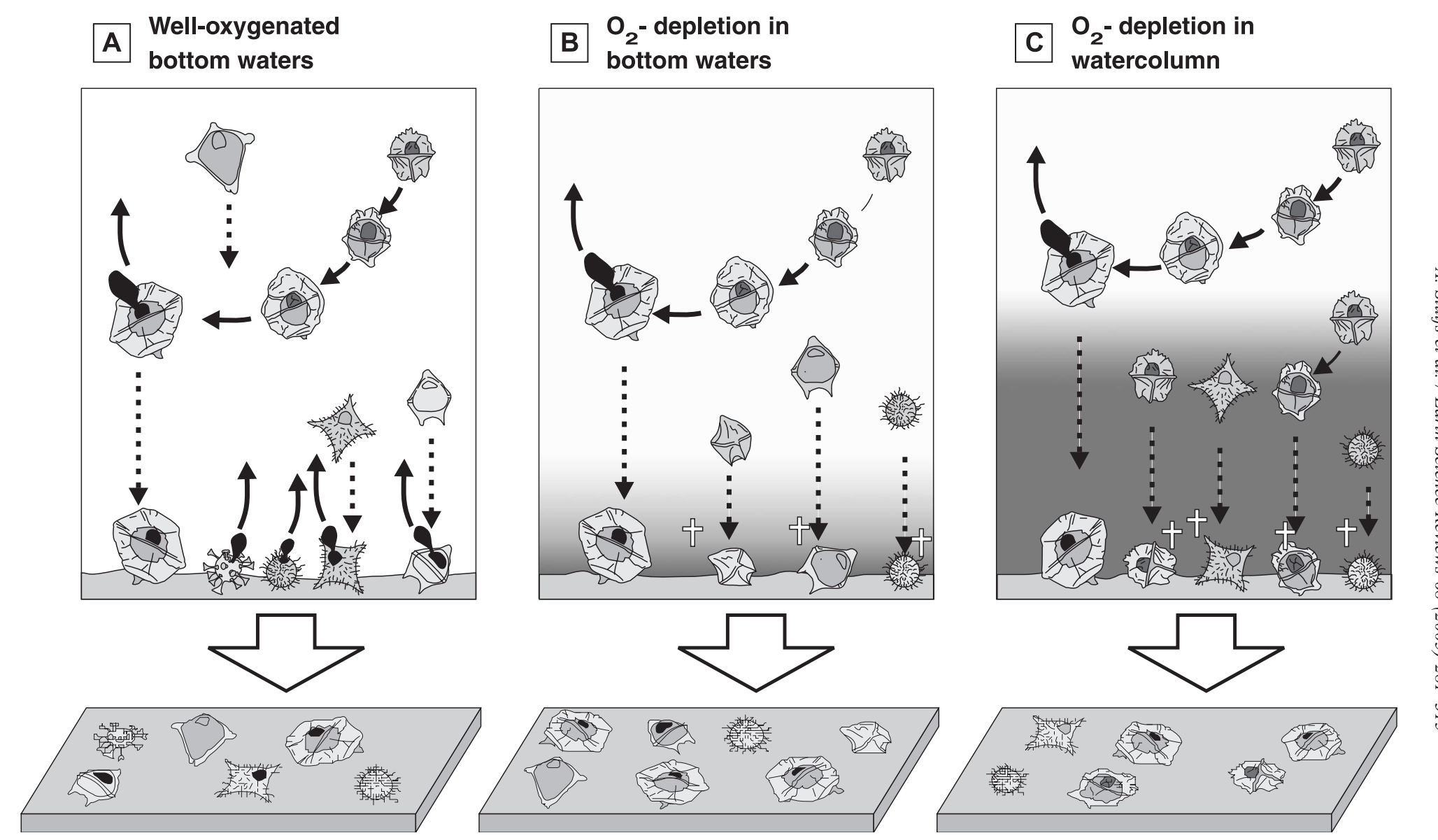

Fig. 14. Schematic model showing reaction of cyst-forming dinoflagellate populations to varying oxygenation levels in the lower Oligocene of the Mainz Basin in southern Germany. (A) During well-oxygenated intervals, dinoflagellates are able to excyst at the seafloor, diversity of cyst-forming dinoflagellates is relatively high and resulting dinocyst assemblages are relatively diverse. (B) Oxygen depletion at the sea floor prohibits excystment and causes dinocyst diversity to decrease. Thalassiphora pelagica is not affected because it excysts in the water column. (C) Oxygen depletion higher in the water column also prevents completion of the T. pelagica life cycle, leading to the preservation of ontogenetically early cyst morphotype. See text for further explanation. Modified from Pross (2001b). 
sity. T. pelagica, in contrast, was not affected because it excysted mainly in the water column. Moreover, the distribution of different $T$. pelagica morphotypes (which Pross, 2001b considered to represent different stages within the cyst part of the $T$. pelagica life cycle; see also von Benedek and Gocht, 1981), appear to be linked to oxygen availability. Horizons with the strongest oxygen depletion and highest $T$. pelagica abundances are also characterized by highest abundances of T. pelagica specimens interpreted to represent an early, unfinished stage in cyst formation. This distribution pattern is interpreted to reflect the extension of low-oxygen conditions higher in the water column, so that even a holoplanktic taxon such as T. pelagica was affected. The completion of the $T$. pelagica life cycle was prevented, which led to the preservation of ontogenetically young morphotypes in the sediment. The model proposed by Pross (2001b) requires a concept for the formation of $T$. pelagica cysts that differs from that known from modern cyst-forming dinoflagellates. However, processes of encystment other than those known from extant forms are possible given the complexity of the dinoflagellate group and the fact that cyst morphogenesis is incompletely known even in most extant cyst-producing dinoflagellate species (Kokinos and Anderson, 1995). In addition, the realization of the model depends on three key environmental factors. Firstly, to yield a benthic signal, dinocysts other than $T$. pelagica must reach the sea floor prior to germination. Based on the sinking rates as observed in modern dinocysts (Anderson et al., 1985; Heiskanen, 1993) and derived from modeling (Sarjeant et al., 1987), this requires water depths not exceeding 150-200 m. Moreover, low-oxygen conditions must temporarily extend into the water column and low-energy hydrodynamic conditions are necessary for the thanatocoenosis on the sediment surface to provide an integrated picture of the biocoenoses in the water column above. These factors can be assumed to be realized in low-oxygen shelf settings. However, further work seems necessary to verify the applicability of this model to dinocyst assemblages from other oxygen-deficient shelf environments and other intervals of the Paleogene. Alternatively, the combined signals might reflect extreme surface salinities, in this case lowered salinities. It is conceivable that an increase in runoff led to reversed density stratification, which obstructed deep ventilation and increased eutrophication of the surface layers, and provided conditions that only $T$. pelagica could cope with. A scenario of strongly abnormal salinity and only $T$. pelagica thriving under these conditions is similar to the record of Polysphaeridium zoharyi from the Arabian Sea, where very high sea surface salinity and hyperstratification prevailed following Heinrich events (Reichart et al., 2004; see Section 7). In the case of the lower Oligocene from the Mainz Embayment, however, low salinities (i.e., brackish conditions) would have prevailed instead of high salinities (i.e., hypersaline conditions). The strong salinity change(s) may have invoked the observed strong morphological variability in $T$. pelagica, perhaps in a similar manner to that observed in extant Lingulodinium machaerophorum. Fossil examples of such extreme morphological changes - comparable to that observed in $T$. pelagica - are known from Galeacysta etrusca during the Messinian salinity crisis in the Mediterranean (Corradini and Biffi, 1988) and have also been observed globally in the 'Cordosphaeridium fibrospinosum complex' sensu Brinkhuis and Schiøler (1996) during the late Cretaceous and Paleogene.

\section{General reconstruction of watermasses and paleoprovincialism}

The global spatial differentiation of dinocyst assemblages (i.e., provincialism) depends on the physiochemical characteristics of the water masses in which the thecal stage developed, and on surface water circulation patterns. Dinocyst provincialism in the fossil record, first recognized in Mesozoic sediments (Norris, 1965; Lentin and Williams, 1980; Goodman, 1987), can be used to trace the direction, origin and intensity of surface currents in the past. For instance, assemblages in a given region that are under the influence of equatorially derived surface currents will become strongly altered if subjected to the influence of a current from high latitudes. Hence, the high diversity in Paleogene dinocyst assemblages may serve as a powerful tool to reconstruct surface water circulation patterns. A good example of provincialism is the distribution of the Antarctic-endemic 
dinocyst assemblage ('Transantarctic Flora' of Wrenn and Beckmann, 1982) during the Eocene. As outlined above (see Section 4), this assemblage has been widely recognized at sites with a paleolatitude south of $\sim 60{ }^{\circ} \mathrm{S}$ and can be readily distinguished from assemblages with more cosmopolitan or tropical affinities (Lentin and Williams, 1976; Wrenn and Hart, 1988; Brinkhuis et al., 2003a,b; Sluijs et al., 2003 and references therein). Hence, the relative amount of Antarctic-endemic versus cosmopolitan taxa can be used to reconstruct the direction and origin of surface currents in this region. Recently, Brinkhuis et al. (2002a,c) and Huber et al. (in press) showed that along the eastern margin of Australia and in New Zealand high percentages of members of the 'Transantarctic Flora' are recorded in lower Paleogene deposits. Based on these and other (Antarcticendemic) paleontological data from the region, and supported through the results of fully coupled General Circulation Model runs, these authors postulate that during the early Paleogene a northward, Antarcticderived surface current flowed along the east coast of Australia, rather than the present-day southward East Australian Current.

\section{Concluding remarks}

Based on combined actuo-paleontological and empirical approaches, organic-walled dinoflagellate cysts provide a powerful tool for the reconstruction of marine environments in the Paleogene. Quaternary studies have demonstrated that organic-walled cystproducing dinoflagellates are sensitive to even the slightest changes in the physiochemical parameters of surface watermasses, indicating their potential for Paleogene studies. Moreover, the cysts are particularly abundant in sediments that were deposited in neritic settings. These factors make the environmental signal that can be derived from dinocysts important, and complementary to the information derived from the traditionally used calcareous and siliceous microfossil groups such as foraminifera, calcareous nannoplankton and radiolaria.

Throughout the paper, we illustrate that dinocysts are indeed highly sensitive indicators for changes in surface water productivity, temperature, and salinity in a wide variety of Paleogene marine settings. In addition, dinocyst assemblages show a pronounced proximal-distal differentiation, which is of relevance for paleoenvironmental reconstructions involving transport, runoff, and sea level change. Finally, recent work indicates that dinocysts may also be useful tools for the reconstruction of surface water eutrophication, stratification, and ventilation of bottom waters and the water column, and are vital for the reconstruction of Paleogene ocean circulation. Altogether, past and ongoing studies have increasingly confirmed the relevance of Paleogene dinocyst analysis for unravelling the mechanisms underlying the Earth's greenhouse-icehouse transition.

Future studies in the still relatively young, but evolving field of organic-walled dinoflagellate cyst (paleo)ecology will result in a refinement of existing approaches, and ultimately yield further increase in both data quality and (paleo)environmental interpretations. In this respect, the results from multi-proxy approaches have proven to be essential. Future studies will certainly also explore the use of molecular geochemical applications of dinocysts.

\section{Acknowledgements}

We gratefully acknowledge the constructive reviews of Erica Crouch and Ian Harding. AS thanks the Utrecht Biogeology Centre for financial support. JP acknowledges support through the German Research Foundation (grant PR 651/1-1) and the Netherlands Organisation for Scientific Research (NWO). This is Netherlands School of Sedimentary Geology (NSG) publication no. 2004.05.07.

\section{References}

Allison, P.A., Wignall, P.B., Brett, C.T., 1995. Palaeo-oxygenation: effects and recognition. In: Bosence, D.W.J., Allison, P.A. (Eds.), Marine Palaeoenvironmental Analysis from Fossils. Special Publication - Geological Society vol. 83, pp. 97-112.

Anderson, D.M., Lively, J.J., Reardon, E.M., Price, C.A., 1985. Sinking characteristics of dinoflagellate cysts. Limnology and Oceanography 30, 1000-1009.

Anderson, D.M., Taylor, C.D., Armbrust, E.V., 1987. The effects of darkness and anaerobiosis on dinoflagellate cyst germination. Limnology and Oceanography 32, 340-351. 
Ayres, M.G., Bilal, M., Jones, R.W., Slentz, L.W., Tartir, M., Wilson, A.O., 1982. Hydrocarbon habitat in main producing areas, Saudi Arabia. American Association of Petroleum Geologists Bulletin 66, 1-9.

Backer, L.C., Fleming, L.E., Rowan, A., Cheng, Y.-S., Benson, J., Pierce, R.H., Zaias, J., Bean, J., Bossart, G.D., Johnson, D., Quimbo, R., Baden, D.G., 2003. Recreational exposure to aerosolized brevetoxins during Florida red tide events. Harmful Algae 2, 19-28.

Backhouse, J., 1988. Late Jurassic and early Cretaceous palynology of the Perth Basin, western Australia. Bulletin - Geological Survey of Western Australia 135, 1-233.

Batten, D.J., Lister, J.K., 1988. Early Cretaceous dinoflagellate cysts and chlorococcalean algae from freshwater and low salinity palynofacies in the English Wealden. Cretaceous Research 9, 337-367.

Batten, D.J., Gray, J., Harland, R., 1999. Palaeoenvironmental significance of a monospecific assemblage of dinoflagellate cysts from the Miocene Clarkia Beds, Idaho, USA. Palaeogeography, Palaeoclimatology, Palaeoecology 153, 161-177.

Berger, W.H., Smetacek, V.S., Wefer, G., 1989. Ocean productivity and paleoproductivity - an overview. In: Berger, W.H., Smetacek, V.S., Wefer, G. (Eds.), Productivity of the Ocean: Present and Past. Life Sciences Research Report vol. 44, pp. 1-34.

Bertrand, P., Shimmield, G., Martinez, P., Grousset, F., Jorissen, F., Paterne, M., Pujol, C., Bouloubassi, I., Buat Menard, P., Peypuquet, J.-P., Beaufort, L., Sicre, M.-A., Lallier-Verges, E., Foster, J.M., Ternois, Y., 1996. The glacial ocean productivity hypothesis: the importance of regional temporal and spatial studies. Marine Geology 130, 1-9.

Boessenkool, K.P., Van Gelder, M.J., Brinkhuis, H., Troelstra, S.R., 2001. Distribution of organic-walled dinoflagellate cysts in surface sediments from transects across the Polar Front offshore southeast Greenland. Journal of Quaternary Science 16 (7), 661-666.

Bohaty, S., Zachos, J.C., 2003. Significant Southern Ocean warming event in the late middle Eocene. Geology 31 (11), 1017-1020.

Bold, H.C., 1973. Morphology of Plants. Harper, New York, $668 \mathrm{pp}$.

Boulter, M.C., Manum, S.B., 1989. The Brito-Arctic igneous province flora around the Paleocene/Eocene boundary. In: Eldholm, O., Thiede, J., Taylor, E. (Eds.), Proceedings of the Ocean Driling Program, Scientific Results. Ocean Drilling Program, College Station, TX, pp. 663-680.

Bowen, G.J., Clyde, W.C., Koch, P.L., Ting, S.Y., Alroy, J., Tsubamoto, T., Wang, Y.Q., Wang, Y., 2002. Mammalian dispersal at the Paleocene/Eocene boundary. Science 295, 2062-2065.

Bradford, M.R., Wall, D.A., 1984. The distribution of recent organic-walled dinoflagellate cysts in the Persian Gulf, Gulf of Oman, and northwestern Arabian Sea. Palaeontographica 192, 16-84.

Brasier, M.D., 1985. Fossil indicators of nutrient levels. 1: eutrophication and climate change. In: Bosence, D.W.J., Allison, P.A. (Eds.), Marine Palaeoenvironmental Analysis from Fossils. Special Publication - Geological Society vol. 83, pp. 113-132.

Brenner, W., 2001. Organic-walled microfossils from the central
Baltic Sea, indicators of environmental change and base for ecostratigraphic correlation. Baltica 14, 40-51.

Brinkhuis, H., 1994. Late Eocene to early Oligocene dinoflagellate cysts from the Priabonian type-area (northeast Italy); biostratigraphy and palaeoenvironmental interpretation. Palaeogeography, Palaeoclimatology, Palaeoecology 107, 121-163.

Brinkhuis, H., Biffi, U., 1993. Dinoflagellate cyst stratigraphy of the Eocene/Oligocene transition in central Italy. Marine Micropaleontology 22, 131-183.

Brinkhuis, H., Schiøler, P., 1996. Palynology of the Geulhemmerberg Cretaceous/Tertiary boundary section (Limburg SE Netherlands). Geologie en Mijnbouw 75 (2/3), 193-213.

Brinkhuis, H., Powell, A.J., Zevenboom, D., 1992. High-resolution dinoflagellate cyst stratigraphy or the Oligocene/Miocene transition interval in north-west and central Italy. In: Head, M.J., Wrenn, J.H. (Eds.), Neogene and Quaternary Dinoflagellate Cysts and Acritarchs. American Association of Stratigraphic Palynologists Foundation, Dallas, pp. 219-258.

Brinkhuis, H., Bujak, J.P., Smit, J., Versteegh, G.J.M., Visscher, H., 1998. Dinoflagellate-based sea surface temperature reconstructions across the Cretaceous-Tertiary boundary. Palaeogeography, Palaeoclimatology, Palaeoecology 141, 67-83.

Brinkhuis, H., Huber, M., Schellenberg, S.A., Stickley, C.E., Sluijs, A., Warnaar, J., Williams, G.L., Exon, N.F., Kennett, J.P., 2002a. Was Antarctica kept warm by subtropical waters in the Eocene? Part 1: evidence from biotic endemism. American Geophysical Union Fall Conference San Francisco, Abstract volume: F925.

Brinkhuis, H., Huber, M., Schellenberg, S.A., Stickley, C.E., Sluijs, A., Warnaar, J., Williams, G.L., Exon, N.F., Kennett, J.P., 2002b. Was Antarctica kept warm by subtropical waters in the Eocene? Part 2: climate model results. American Geophysical Union Fall Conference, San Francisco, Abstract volume: F926.

Brinkhuis, H., Munsterman, D.K., Sengers, S., Sluijs, A., Warnaar, J., Williams, G.L., 2003a. Late Eocene to Quaternary dinoflagellate cysts from ODP Site 1168, Off western Tasmania. In: Exon, N.F., Kennett, J.P., Malone, M. (Eds.), Proceedings of the Ocean Drilling Program. Scientific Results vol. 189, pp. 1-36. Available from World Wide Web: http://www-odp. tamu.edu/publications/189_SR/105/105.htm. [Cited 2003-1028], College Station, TX.

Brinkhuis, H., Sengers, S., Sluijs, A., Warnaar, J., Williams, G.L., 2003b. Latest Cretaceous to earliest Oligocene, and Quaternary dinoflagellate cysts from ODP Site 1172, East Tasman Plateau. In: Exon, N.F., Kennett, J.P., Malone, M. (Eds.), Proceedings of the Ocean Drilling Program. Scientific Results vol. 189, pp. 1-48. Available from World Wide Web: http://www-odp. tamu.edu/publications/189_SR/106/106.htm. [Cited 2003-1031], College Station, TX.

Brinkhuis, H., Huber, M., Sluijs, A., Zachos, J.C., Warnaar, J., 2003c. The end of the early Eocene Climatic Optimum: Evidence for Concomitant Cooling of Southern Ocean Surface Waters and Global Deep Waters From Dinoflagellate Endemism. American Geophysical Union Fall Conference San Francisco, Abstract volume: F887.

Bucefalo-Palliani, R., Mattioli, E., Riding, J.B., 2002. The re- 
sponse of marine phytoplankton and sedimentary organic matter to the early Toarcian (lower Jurassic) oceanic anoxic event in northern England. Marine Micropaleontology 46 (3-4), 223-245.

Bujak, J.P., Brinkhuis, H., 1998. Global warming and dinocyst changes across the Paleocene/Eocene Epoch boundary. In: Aubry, M.-P. (Ed.), Late Paleocene-Early Eocene Biotic and Climatic Events in the Marine and Terrestrial Records. Columbia Univ. Press, New York, pp. 277-295.

Bujak, J.P., Williams, G.L., 1979. Dinoflagellate diversity through time. Marine Micropaleontology 4, 1-12.

Cembella, A.D., Quilliam, M.A., Lewis, N.I., Bauder, A.G., Dell'Aversano, C., Thomas, K., Jellett, J., Cusack, R.R., 2002. The toxigenic marine dinoflagellate Alexandrium tamarense as the probable cause of mortality of caged salmon in Nova Scotia. Harmful Algal Blooms 1, 313-325.

Coccioni, R., Basso, D., Brinkhuis, H., Galeotti, S., Gardin, S., Monechi, S., Spezzaferri, S., 2000. Marine biotic signals across a late Eocene impact layer at Massignano, Italy: evidence for long-term environmental perturbations? Terra Nova $12,258-263$.

Corradini, D., Biffi, U., 1988. Etude des dinokystes à la limite messinien-pliocène dans la coupe Cava Serredi, Toscane, Italie (Dinocysts at the Messinian-Pliocene boundary in the Cava Serredi section, Tuscany, Italy). Bulletin des Centres de Recherches Exploration-Production Elf-Aquitaine 12 (1), 221-236.

Crouch, E.M., 2001. Environmental change at the time of the Paleocene-Eocene biotic turnover. Laboratory of Palaeobotany and Palynology Contribution Series 14, 216 pp.

Crouch, E.M., Heilmann-Clausen, C., Brinkhuis, H., Morgans, H.E.G., Rogers, K.M., Egger, H., Schmitz, B., 2001. Global dinoflagellate event associated with the late Paleocene Thermal Maximum. Geology 29 (4), 315-318.

Crouch, E.M., Brinkhuis, H., Visscher, H., Adatte, T., Bolle, M.-P., 2003a. Late Paleocene-early Eocene dinoflagellate cyst records from the Tethys: further observations on the global distribution of Apectodinium. In: Wing, S.L., Gingerich, P.D., Schmitz, B., Thomas, E. (Eds.), Causes and Consequences of Globally Warm Climates in the Early Paleogene. Special Paper - Geological Society of America 369, 113-131.

Crouch, E.M., Dickens, G.R., Brinkhuis, H., Aubry, M.-P., Hollis, C.J., Rogers, K.M., Visscher, H., 2003b. The Apectodinium acme and terrestrial discharge during the Paleocene-Eocene Thermal Maximum: new palynological, geochemical and calcareous nannoplankton observations at Tawanui, New Zealand. Palaeogeography, Palaeoclimatology, Palaeoecology 194, $387-403$.

Dale, B., 1983. Dinoflagellate resting cysts: "benthic plankton". In: Fryxell, G.A. (Ed.), Survival Strategies of the Algae. Cambridge Univ. Press, Cambridge, pp. 69-136.

Dale, B., 1996. Dinoflagellate cyst ecology: modeling and geological applications. In: Jansonius, J., McGregor, D.C. (Eds.), Palynology: Principles and Applications. American Association of Stratigraphic Palynologists Foundation, Dallas, pp. 1249-1276.

Dale, B., 2001. The sedimentary record of dinoflagellate cysts: looking back into the future of phytoplankton blooms. Scientia Marina 65, 257-272.
Dale, B., Dale, A.L., 1992. Dinoflagellate contributions to the deep sea. Ocean Biocoenosis Series 5, 1-77.

Dale, B., Fjellså, A., 1994. Dinoflagellate cysts as paleoproductivity indicators: state of the art, potential and limits. In: Zahn, R., Pedersen, T.F., Kaminski, M.A., Labeyrie, L. (Eds.), Carbon Cycling in the Glacial Ocean: Constraints on the Ocean's Role in Global Change. Springer, Berlin, pp. 521-537.

de Vernal, A., Mudie, P.J., 1992. Pliocene and Quaternary dinoflagellate cyst stratigraphy in the Labrador Sea: paleoenvironmental implications. In: Head, M.J., Wrenn, J.H. (Eds.), Neogene and Quaternary Dinoflagellate Cysts and Acritarchs. American Association of Stratigraphic Palynologists Foundation, Dallas, pp. 329-436.

de Vernal, A., Goyette, C., Rodrigues, C.G., 1989. Contribution palynostratigraphique (dinokystes, pollen et spores) à la connaissance de la mer de Champlain: coupe de Saint Cezaire, Québec. Canadian Journal of Earth Sciences 26, 2450-2464.

de Vernal, A., Turon, J.-L., Guiot, J., 1993. Dinoflagellate cyst distribution in high-latitude marine environments and quantitative reconstruction of sea-surface salinity, temperature, and seasonality. Canadian Journal of Earth Sciences 31, 48-62.

de Vernal, A., Turon, L., Guiot, J., 1994. Dinoflagellate distribution in high-lattitude marine environments and quantitative reconstruction of sea-surface salinity, temperature and seasonality. Canadian Journal of Earth Sciences 31, 48-62.

de Vernal, A., Rochon, A., Turon, J.-L., Matthiessen, J., 1998. Organic-walled dinoflagellate cysts: palynological tracers of sea-surface conditions in middle to high latitude marine environments. Geobios 30, 905-920.

de Vernal, A., Hillaire-Marcel, C., Turon, J.-L., Matthiessen, J., 2000. Reconstruction of sea-surface temperature, salinity, and sea-ice cover in the northern North Atlantic during the last glacial maximum based on dinocyst assemblages. Canadian Journal of Earth Sciences 37, 725-750.

de Vernal, A., Matthiessen, J., Mudie, P.J., Rochon, A., Boessenkool, K.P., Eynaud, F., Grøsfjeld, K., Guiot, J., Hamel, D., Harland, R., Head, M.J., Kunz-Pirrung, M., Loucheur, V., Peyron, O., Pospelova, V., Radi, T., Turon, J.-L., Voronina, E., 2001. Dinoflagellate cyst assemblages as tracers of sea-surface conditions in the northern North Atlantic, Arctic and sub-Arctic seas: the new "n-677" data base and its application for quantitative paleoceanographic reconstruction. Journal of Quaternary Science 16, 681-698.

Devillers, R., de Vernal, A., 2000. Distribution of dinoflagellate cysts in surface sediments of the northern North Atlantic in relation to nutrient content and productivity in surface waters. Marine Geology 166, 103-124.

Downie, C., Hussain, M.A., Williams, G.L., 1971. Dinoflagellate cyst and acritarch associations in the Paleogene of southeast England. Geoscience and Man 3, 29-35.

Edwards, L.E., 1989. Dinoflagellate Cysts from the Lower Tertiary Formations, Haynesville Cores, Richmond County, Virginia, Geology and Paleontology of the Haynesville Cores-Northeastern Virginia Coastal Plain. US, Geological Survey Professional Paper vol. 1489-C. US Government Printing Office, Washington, p. 23.

Edwards, L.E., Andrle, V.A., 1992. Distribution of selected dino- 
flagellate cysts in modern sediments. In: Head, M.J., Wrenn, J.H. (Eds.), Neogene and Quaternary Dinoflagellate Cysts and Acritarchs. American Association of Stratigraphic Palynologists Foundation, Dallas, TX, pp. 259-288.

Ellegaard, M., 2000. Variations in dinoflagellate cyst morphology under conditions of changing salinity during the last 2000 years. Review of Palaeobotany and Palynology 109, 65-81.

Emerson, S., Hedges, J.I., 1988. Processes controlling the ocean carbon content of open ocean sediments. Paleoceanography 3 , $621-634$.

Eshet, Y., Almogi, L.A., Bein, A., 1994. Dinoflagellate cysts, paleoproductivity and upwelling systems; a late Cretaceous example from Israel. Marine Micropaleontology 23 (2), 231-240.

Fensome, R.A., Taylor, F.J.R., Norris, G., Sarjeant, W.A.S., Wharton, D.I., Williams, G.L., 1993. A classification of fossil and living dinoflagellates. Micropaleontology Special Publication 7, $351 \mathrm{pp}$.

Fensome, R.A., Gocht, H., Williams, G.L., 1996a. The Eisenack Catalog of Fossil Dinoflagellates, New Series vol. 4. E. Schweizerbart'sche Verlagsbuchhandlung, Stuttgart, Germany, pp. 2009-2548.

Fensome, R.A., MacRae, R.A., Moldowan, J.M., Taylor, F.J.R., Williams, G.L., 1996b. The early Mesozoic radiation of dinoflagellates. Paleobiology 22, 329-338.

Firth, J.V., 1996. Upper middle Eocene to Oligocene dinoflagellate biostratigraphy and assemblage variations in hole 913B, Greenland Sea. In: Thiede, J., Myrhe, A.M., Firth, J.V., Johnson, G.L., Ruddiman, W.F. (Eds.), Proceedings of the Ocean Drilling Program. Scientific Results, pp. 203-242.

Fogg, G.E., 2002. Harmful Algae - a perspective. Harmful Algae 1, $1-4$.

Galeotti, S., Brinkhuis, H., Huber, M., 2004. Record of post-K-T boundary millennial-scale cooling from the western Tethys: a smoking gun for the impact-winter hypothesis? Geology 32, $529-532$.

Gavrilov, Y., Shcherbinina, E.A., Oberhänsli, H., 2003. PaleoceneEocene boundary events in the northeastern Peri-Tethys. In: Wing, S.L., Gingerich, P.D., Schmitz, B., Thomas, E. (Eds.), Causes and Consequences of Globally Warm Climates in the Early Paleogene. Special Paper - Geological Society of America $369,147-168$.

Goodman, D.K., 1987. Dinoflagellate cysts in ancient and modern sediments. In: Taylor, F.J.R. (Ed.), The Biology of Dinoflagellates, Botanical Monographs vol. 21, pp. 649-722.

Goodman, D.K., Ford, L.N., 1983. Preliminary dinoflagellate biostratigraphy for the middle Eocene to lower Oligocene from the Southwest Atlantic Ocean. In: Ludwig, W.J., Krasheninikov, V.A. (Eds.), Initial Reports of the Deep Sea Drilling Project vol. 71, pp. 859-877.

Gradstein, F.M., Kristiansen, I.L., Loemo, L., Kaminski, M.A., 1992. Cenozoic foraminiferal and dinoflagellate cyst biostratigraphy of the central North Sea. Micropaleontology 38, 101-137.

Grøsfjeld, K., Larsen, E., Sejrup, H.-P., de Vernal, A., Flatebf, T., Vestbf, M., Haflidason, H., Aarseth, I., 1999. Dinoflagellate cysts reflecting surface-water conditions in Voldafjorden, western Norway during the last 11.300 years. Boreas 28, 403-415.

Habib, D., Miller, J.A., 1989. Dinoflagellate species and organic facies evidence of marine transgression and regression in the Atlantic coastal plain. Palaeogeography, Palaeoclimatology, Palaeoecology 74, 23-47.

Habib, D., Moshkovitz, S., Kramer, C., 1992. Dinoflagellate and calcareous nannofossil response to sea-level change in Cretaceous-Tertiary boundary sections. Geology 20, 165-168.

Haeckel, E., 1894. Systematische Phylogenie. Entwurf eines natürlichen Systems der Organismen auf Grund ihrer Stammegeschichte. I: Systematische Phylogenie der Protisten und Pflanzen Reimer, Berlin. 400 pp.

Hallegraeff, G.M., 1993. A review of harmful algal blooms and their apparent global increase. Phycologia 32, 79-99.

Haq, B.U., Hardenbol, J., Vail, P.R., 1987. Chronology of fluctuating sea levels since the Triassic. Science 235, 1156-1167.

Haq, B.U., Hardenbol, J., Vail, P.R., 1988. Mesozoic and Cenozoic chronostratigraphy and cycles of sea level change. In: Wilgus, C.K., Hastings, B.S. (Eds.), Sea Level Changes: An Integrated Approach. Special Publication - Society of Economic Paleontologists and Mineralogists vol. 42, pp. 71-108.

Harland, R., 1973. Dinoflagellate cysts and acritarchs from the Bearpaw Formation (upper Campanian) of southern Alberta, Canada. Palaeontology 16, 665-706.

Harland, R., 1983. Distribution maps of recent dinoflagellate in bottom sediments from the North Atlantic Ocean and adjacent seas. Palaeontology 26, 321-387.

Harland, R., Long, D., 1996. A Holocene dinoflagellate cyst record from offshore north-east England. Proceedings of the Yorkshire Geological Society 51 (1), 65-74.

Head, M.J., 1996. Modern dinoflagellate cysts and their biological affinities. In: Jansonius, J., McGregor, D.C. (Eds.), Palynology: Principles and Applications. American Association of Stratigraphic Palynologists Foundations, Dallas, TX, pp. 1197-1248.

Head, M.J., Norris, G., 1989. Palynology and dinocyst stratigraphy of the Eocene and Oligocene in ODP Leg 105, Hole 647A, Labrador Sea. In: Stewart, S.K. (Ed.), Proceedings of the Ocean Drilling Program. Scientific Results, pp. 515-550.

Heil, C.A., Glibert, P.M., Al-Sarawi, M.A., Faraj, M., Behbehani, M., Husain, M., 2001. First record of a fish-killing Gymnodinium sp. bloom in Kuwait Bay, Arabian Sea: chronology and potential causes. Marine Ecology, Progress Series 214, 15-23.

Heiskanen, A.S., 1993. Mass encystment and sinking of dinoflagellates during a spring bloom. Marine Biology 116, 161-167.

Hochuli, P.A., Frank, S.M., 2000. Palynology (dinoflagellate cysts, spores, and pollen) and stratigraphy of the Lower Carnian Raibl Group. Eclogae Geologicae Helvetiae 93, 429-443.

Horner, R.A., 1985. Sea Ice Biota CRC Press, Boca Raton. 215 pp.

Huber, M., Sloan, L.C., 2001. Heat transport, deep waters, and thermal gradients: coupled simulation of an Eocene "greenhouse" climate. Geophysical Research Letters 28, 3481-3484.

Huber, M., Brinkhuis, H., Stickley, C.E., Döös, K., Sluijs, A., Warnaar, J., Schellenberg, S.A. and Williams, G.L., in press. Eocene circulation of the Southern Ocean: was Antarctica kept warm by subtropical waters? Paleoceanography.

Hultberg, S.U., 1987. Palynological evidence for a diachronous low-salinity event in the C-T boundary clay at Stevns Klint, Denmark. Journal of Micropalaeontology 6 (2), 35-40.

Iakovleva, A.I., Brinkhuis, H., Cavagnetto, C., 2001. Late Palae- 
ocene-early Eocene dinoflagellate cysts from the Turgay Strait, Kazakhstan; correlations across ancient seaways. Palaeogeography, Palaeoclimatology, Palaeoecology 172, 243-268.

Jan du Chêne, R.E., Adediran, S.A., 1984. Late Paleocene to early Eocene dinoflagellates from Nigeria. Cahiers de Micropaléontologie 3,88 .

Jarvis, I., Carson, G.A., Cooper, M.K.E., Hart, M.B., Leary, P.N., Tocher, B.A., Horne, D., Rosenfeld, A., 1988. Microfossil assemblages and the Cenomanian-Turonian (late Cretaceous) Oceanic Anoxic Event (OAE). Cretaceous Research 9, 3-103.

Kennett, J.P., Stott, L.D., 1991. Abrupt deep-sea warming, palaeoceanographic changes and benthic extinctions at the end of the Palaeocene. Nature 353, 225-229.

Koch, P.L., Zachos, J.C., Gingerich, P.D., 1992. Correlation between isotope records in marine and continental carbon reservoirs near the Palaeocene/Eocene boundary. Nature 358, 319-322.

Kokinos, J.P., Anderson, D.M., 1995. Morphological development of resting cysts in cultures of the marine dinoflagellate Lingulodinium polyedrum (=L. machaerophorum). Palynology 19, $143-166$.

Köthe, A., 1990. Paleogene dinoflagellates from northwest Germany. Geologisches Jahrbuch 118, 1-111.

Köthe, A., Khan, A.M., Ashraf, M., 1988. Biostratigraphy of the Surghar Range, Salt Range, Sulaiman Range and the Kohat area, Pakistan, according to Jurassic through Paleogene Calcareous Nannofossils and Paleogene Dinoflagellates, Geologisches Jahrbuch. Reihe B vol. 71. Bundesanstalt für Geowissenschaften und Rohnstoffe und den Geologischen Landesämtern in der Bundesrepublik Deutschland, Hannover, $87 \mathrm{pp}$.

Kouli, K., Brinkhuis, H., Dale, B., 2001. Spiniferites cruciformis: a fresh water dinoflagellate cyst? Review of Palaeobotany and Palynology 113, 273-286.

Krutzsch, W., 1962. Die Mikroflora der Geiseltalbraunkohle: Teil III. Süßwasserdinoflagellaten aus subaquatisch gebildeten Blätterkohlenlagen des mittleren Geiseltales. Hallesches Jahrbuch für Mitteldeutsche Erdgeschichte 4, 40-45.

Leckie, D.A., Singh, C., Bloch, J., Wilson, M., Wall, J., 1992. An anoxic event at the Albian-Cenomanian boundary: the Fish Scale Marker Bed, northern Alberta, Canada. Palaeogeography, Palaeoclimatology, Palaeoecology 92, 139-166.

LeHérissé, A., Masure, E., Al Ruwaili, M., Massa, D., 2000. Revision of Arpylorus antiquus from the Silurian: the end of a myth. In: Wang, W., Quyang, S., Sun, X., Yu, G. (Eds.), Abstracts 10th International Palynological Congress, Nanjing. National Natural Science Foundation of China, p. 88.

Lentin, J.K., Williams, G.L., 1976. A Monograph of Fossil Peridinioid Dinoflagellate Cysts, Report Series - Bedford Institute of Oceanography vol. BI-R-75-16. Bedford Institute of Oceanography, Dartmouth, NS, $237 \mathrm{pp}$.

Lentin, J.K., Williams, G.L., 1980. Dinoflagellate provincialism with emphasis on Campanian peridiniaceans. Contribution Series American Association of Stratigraphic Palynologists 7, 1-47.

Lewis, J., Hallet, R., 1997. Lingulodinium polyedrum (Gonyaulax polyedra), a blooming dinoflagellate. Oceanography and Marine Biology Annual Review 35, 97-161.
Lewis, J., Rochon, A., Harding, I., 1999. Preliminary observations of cyst-theca relationships in Spiniferites ramosus and Spiniferites membranaceus (Dinophyceae). Grana 38, 113-124.

Lewis, J., Ellegaard, M., Hallett, R., Harding, I., Rochon, A., 2003. Environmental control of cyst morphology in Gonyaulacoid dinoflagellates. In: Matsuoka, K., Yoshida, M., Iwataki, M. (Eds.), Dino7, Seventh International Conference on Modern and fossil Dinoflagellates, Abstract Volume. Additional Abstract.

MacRae, R.A., Fensome, R.A., Williams, G.L., 1996. Fossil dinoflagellate diversity, originations, and extinctions and their significance. Canadian Journal of Botany 74, 1687-1694.

Manum, S.B., 1960. Some dinoflagellates and hystrichosphaerids from the lower Tertiary of Spitsbergen. Nytt Magasin for Botanikk 8, 17-26.

Manum, S.B., Boulter, M.C., Gunnarsdottir, H., Ragnes, K., Scholze, A., 1989. Eocene to Miocene palynology of the Norwegian Sea (ODP leg 104). In: Eldholm, O., Thiede, J., Taylor, E. (Eds.), Proceedings of the Ocean Drilling Program. Scientific Results vol. 104, pp. 611-661.

Mao, S., Mohr, B.A.R., 1995. Middle Eocene dinoflagellate paleoenvironmental and paleogeographic conclusions. Review of Palaeobotany and Palynology 86, 235-263.

Marret, F., Scourse, J., 2002. Control of modern dinoflagellate cyst distribution in the Irish and Celtic seas by seasonal stratification dynamics. Marine Micropaleontology 47, 101-116.

Marshall, K.L., Batten, D.J., 1988. Dinoflagellate cyst associations in Cenomanian-Turonian "black shale" sequences of northern Europe. Review of Palaeobotany and Palynology 54, $85-103$.

Matsuoka, K., 1992. Species diversity of modern dinoflagellate cysts in surface sediments around the Japanese Islands. In: Head, M.J., Wrenn, J.H. (Eds.), Neogene and Quaternary Dinoflagellate Cysts and Acritarchs. American Association of Stratigraphic Palynologists Foundation, Dallas, pp. 33-53.

Matsuoka, K., Yoshida, M., Iwataki, M. (Eds.), 2003. Dino7, Seventh International Conference on Modern and Fossil Dinoflagellates, Nagasaki. Abstract volume, 152 pp.

Matthiessen, J., Brenner, W., 1996. Chlorococcalalgen und Dinoflagellatenzysten in rezenten Sedimenten des Greifswalder Boddens (südliche Ostsee). Senckenbergiana Maritima 27, $33-48$.

McMinn, A., 1995. Why are there no post-Paleogene dinoflagellate cysts in the Southern Ocean? Micropaleontology 41 (4), 383-386.

Miller, K.G., Wright, J.D., Fairbanks, R.G., 1991. Unlocking the Ice House: Oligocene-Miocene oxygen isotopes, eustasy and margin erosion. Journal of Geophysical Research 96, 6829-6848.

Miller, K.G., Mountain, G.S., Browning, J.V., Kominz, M., Sugerman, P.J., Christie-Blick, N., Katz, M.E., Wright, J.D., 1998. Cenozoic global sea level, sequences, and the New Jersey transect: results from coastal plain and continental slope drilling. Reviews of Geophysics 36, 569-601.

Moldowan, J.M., Talyzina, N.M., 1998. Biogeochemical evidence for dinoflagellate ancestors in the early Cambrian. Science 281, 1168-1170.

Moshkovitz, S., Habib, D., 1993. Calcareous nannofossil and dino- 
flagellate stratigraphy of the Cretaceous-Tertiary boundary, Alabama, and Georgia. Micropaleontology 39, 167-191.

Mudie, P.J., Harland, R., 1996. Aquatic Quaternary. In: Jansonius, J., McGregor, D.C. (Eds.), Palynology: Principles and Applications. American Association of Stratigraphic Palynologists Foundation, Dallas, pp. 843-877.

Mudie, P.J., Aksu, A.E., Yasar, D., 2001. Late Quaternary dinoflagellate cysts from the Black, Marmara and Aegean Seas: variations in assemblages, morphology and paleosalinity. Marine Micropaleontology 43, 155-178.

Mudie, P.J., Rochon, A., Aksu, A.E., Gillespie, H., 2002. Dinoflagellate cysts, freshwater algae and fungal spores as salinity indicators in late Quaternary cores from Marmara and Black seas. In: Aksu, A.E., Yaltirak, C. (Eds.), Quaternary paleoclimatic-paleoceanographic and tectonic evolution of the Marmara Sea and environs; a collection of papers dedicated to the memory of Dr. Ihsan Ketin. Marine Geology 190, 1-2: 203-231.

Nehring, S., 1994a. Dinoflagellaten-Dauercysten in deutschen Küstengewässern: Vorkommen, Verbreitung und Bedeutung als Rekrutierungspotential. Berichte des Instituts für Meereskunde der Christian-Albrechts-Universität Kiel 259, 1-231.

Nehring, S., 1994b. Spatial distribution of dinoflagellate resting cysts in Recent sediments of Kiel Bight, Germany (Baltic Sea). Ophelia 39, 137-158.

Nicoll, R.S., Foster, C.B., 1994. Late Triassic conodont and palynomorph biostratigraphy and conodont thermal maturation, North West Shelf, Australia. Journal of Australian Geology and Geophysics 15, 1-101.

Nohr-Hansen, H., 2003. Dinoflagellate cyst stratigraphy of the Palaeogene strata from the Hellefisk-1, Ikermiut-1, Kangamiut-1, Nukik-1, Nukik-2 and Qulleq-1 wells, offshore West Greenland. Marine and Petroleum Geology 20 (9), 987-1016.

Norris, G., 1965. Provincialism of Callovian-Neocomian dinoflagellate cysts in the northern and southern hemispheres. Contribution Series - American Association of Stratigraphic Palynologists 4, 29-35.

Norris, R.D., Röhl, U., 1999. Carbon cycling and chronology of climate warming during the Palaeocene/Eocene transition. Nature 401, 775-778.

Patten, B.C., 1962. Species diversity in net phytoplankton of Raritan Bay. Journal of Marine Research 20, 57-75.

Peeters, F.J.C., Hoek, R.P., Brinkhuis, H., Wilpshaar, M., de Boer, P.L., Krijgsman, W., Meulenkamp, J.E., 1998. Differentiating glacio-eustasy and tectonics; a case study involving dinoflagellate cysts from the Eocene-Oligocene of the Pindos Foreland Basin (NW Greece). Terra Nova 10, 245-249.

Pope, K.O., Baines, K.H., Ocampo, A.C., Ivanov, B.A., 1997. Energy, volatile production, and climatic effects of the Chicxulub Cretaceous/Tertiary impact. Journal of Geophysical Research $102,21.645-21.664$.

Poulsen, N.E., Manum, S.B., Williams, G.L., Ellegaard, M., 1996. Tertiary dinoflagellate biostratigraphy of sites 907,908 and 909 in the Norwegian-Greenland Sea. In: Riegel, R.N. (Ed.), Proceedings of the Ocean Drilling Program. Scientific Results vol. 151 , pp. $255-287$.

Powell, A.J., Lewis, J., Dodge, J.D., 1992. The palynological expressions of post-Paleogene upwelling: a review. In: Summerhayes, C.P., Prell, W.L., Emeis, K.C. (Eds.), Upwelling Systems: Evolution since the Early Miocene. The Geological Society, London, pp. 215-226.

Powell, A.J., Brinkhuis, H., Bujak, J.P., 1996. Upper Paleocenelower Eocene dinoflagellate cyst sequence biostratigraphy of southeast England. In: Knox, R.W.O.B., Corfield, R.M., Dunay, R.S. (Eds.), Correlation of the Early Paleogene in Northwest Europe. Special Publication - Geological Society vol. 101, pp. 145-183.

Pross, J., 2001a. Dinoflagellate cyst biogeography and biostratigraphy as a tool for palaeoceanographic reconstructions: an example from the Oligocene of western and northwestern Europe. In: Luterbacher, H., Pross, J., Wille, W. (Eds.), Studies in dinoflagellate cysts in honour of Hans Gocht. Neues Jahrbuch für Geologie und Paläontologie, Abhandlungen, pp. 207-219.

Pross, J., 2001b. Paleo-oxygenation in Tertiary epeiric seas: evidence from dinoflagellate cysts. Palaeogeography, Palaeoclimatology, Palaeoecology 166, 369-381.

Pross, J., Schmiedl, G., 2002. Early Oligocene dinoflagellate cysts from the Upper Rhine Graben (SW Germany): paleoenvironmental and paleoclimatic implications. Marine Micropaleontology $45,1-24$.

Pross, J., Kotthoff, U., Zonneveld, K.A.F., 2004. Die Anwendung organischwandiger Dinoflagellatenzysten zur Rekonstruktion von Paläoumwelt, Paläoklima und Paläozeanographie: Möglichkeiten und Grenzen. Paläontologische Zeitschrift 78, 5-39.

Reichart, G.-J., Brinkhuis, H., 2003. Late Quaternary Protoperidinium cysts as indicators of paleoproductivity in the northern Arabian Sea. Marine Micropaleontology 49 (4), 303-370.

Reichart, G.J., Brinkhuis, H., Huiskamp, F., Zachariasse, W.J., 2004. Hyper-stratification following glacial overturning events in the northern Arabian Sea. Paleoceanography 19 (2): PA2013 (10.1029/2003PA000300).

Rochon, A., de Vernal, A., Sejrup, H.-P., Haflidason, H., 1998. Palynological evidence of climatic and oceanographic changes in the North Sea during the last deglaciation. Quaternary Research 49, 197-207.

Rochon, A., de Vernal, A., Turon, J.L., Mathiessen, J., Head, M.J., 1999. Distribution of recent dinoflagellate cysts in surface sediments from the North Atlantic Ocean and adjacent seas in relation to sea-surface parameters. Contribution Series - American Association of Stratigraphic Palynologists Foundation 35, 152 pp.

Rognon, P., Coudé-Gaussen, G., 1996. Paleoclimates off Northwest Africa $\left(28^{\circ}-35^{\circ} \mathrm{N}\right)$ about 18,000 yr B.P. based on continental eolian deposits. Quaternary Research 46, 118-126.

Röhl, U., Brinkhuis, H., Sluijs, A., Fuller, M., in press (a). On the search for the Paleocene/Eocene boundary in the Southern Ocean: Exploring ODP Leg 189 Holes 1171D and 1172D, Tasman Sea. In: N.F. Exon, M. Malone and J.P. Kennett (Eds.), Climate evolution of the Southern Ocean and Australia's northward flight from Antarctica; American Geophysical Union Geophysical Research Series.

Röhl, U., Brinkhuis, H., Stickley, C.E., Fuller, M., Schellenberg, S.A., Wefer, G., Williams, G.L., in press (b). Sea level and 
astronomically induced environmental changes in middle and late Eocene sediments from the East Tasman Plateau. In: Exon, N.F., Malone, M., Kennett, J.P. (Eds.), Climate evolution of the Southern Ocean and Australia's northward flight from Antarctica; American Geophysical Union Geophysical Research Series.

Sangiorgi, F., Capotondi, L., Brinkhuis, H., 2002. A centennial scale organic-walled dinoflagellate cyst record of the last deglaciation in the South Adriatic Sea (central Mediterranean). Palaeogeography, Palaeoclimatology, Palaeoecology 186 (3-4), 199-216.

Sangiorgi, F., Capotondi, L., Combourieu Nebout, N., Vigliotti, L., Brinkhuis, H., Giunta, S., Lotter, A.F., Morigi, C., Negri, A., Reichart, G.J., 2003. Holocene seasonal sea surface temperature variations in the South Adriatic Sea inferred from a multi-proxy approach. Journal of Quaternary Science 18 (8), 723-732.

Sarjeant, W.A.S., 1978. Arpylorus antiquus Calandra emend., a dinoflagellate cyst from the upper Silurian. Palynology 2, 167-179.

Sarjeant, W.A.S., Lacalli, T., Gaines, G., 1987. The cysts and skeletal elements of dinoflagellates: speculations on the ecologic causes for their morphology and development. Micropaleontology $33,1-36$.

Sarnthein, M., Winn, K., Duplessy, J.C., Fontugne, M.R., 1988. Global variations of surface ocean productivity in low and middle latitudes: influence on $\mathrm{CO}_{2}$ reservoirs of deep ocean and atmosphere during the last 21,000 years. Paleoceanography 3, 361-399.

Schellenberg, S.A., Brinkhuis, H., Stickley, C.E., Fuller, M., Kyte, F.T., Williams, G.L., in press. The Cretaceous/Paleogene transition on East Tasman Plateau, southwestern Pacific. In: Exon, N.F., Malone, M., Kennett, J.P. (Eds.), Climate evolution of the Southern Ocean and Australia's northward flight from Antarctica. American Geophysical Union Geophysical Research Series.

Shimmield, G.B., 1992. Can sediment geochemistry record changes in coastal upwelling palaeoproductivity? Evidence from northwest Africa and the Arabian Sea. In: Summerhayes, C.P., Prell, W.L., Emeis, K.C. (Eds.), Upwelling Systems: Evolution since the Early Miocene. Special Publication - Geological Society vol. 64, pp. $29-46$.

Sluijs, A., Brinkhuis, H., Stickley, C.E., Warnaar, J., Williams, G.L., Fuller, M., 2003. Dinoflagellate cysts from the Eocene/ Oligocene transition in the Southern Ocean; results from ODP Leg 189. In: Exon, N.F., Kennett, J.P., Malone, M.J. (Eds.), Proceedings of the Ocean Drilling Program. Scientific Results vol. 189, pp. 1-42. Available from World Wide Web: http:// www-odp.tamu.edu/publications/189_SR/104/104.htm. [Cited 2003-10-22]. College Station, TX.

Speijer, R.P., Van der Zwaan, G.J., Schmitz, B., 1996. The impact of Paleocene/ Eocene boundary events on middle neritic benthic foraminiferal assemblages from Egypt. Marine Micropaleontology 28 (2), 99-132.

Spero, H.J., 1987. Symbiosis in the planktonic foraminifer, Orbulina universa, and the isolation of its symbiotic dinoflagellate, Gymnodinium beii sp. nov.. Journal of Phycology 23, 307-317.
Sprangers, M., Dammers, N., Brinkhuis, H., van Weering, T.C.E., Lotter, A.F., 2004. Modern organic-walled dinoflagellate cyst distribution offshore NW Iberia; tracing the upwelling system. Review of Palaeobotany and Palynology 128 (12), 97-106.

Steurbaut, E., Magioncalda, R., Dupuis, C., van Simaeys, S., Roche, E., Roche, M.-I.E., 2003. Palynology, paleoenvironments, and organic carbon isotope evolution in lagoonal Paleocene-Eocene boundary settings in North Belgium. In: Wing, S., Gingerich, P., Schmitz, B., Thomas, E. (Eds.), Causes and Conequences of Globally Warm Climates in the Early Paleogene. Special Paper - Geological Society of America 369, 291 317.

Stickley, C.E., Brinkhuis, H., Schellenberg, S.A., Sluijs, A., Fuller, M., Grauert, M., Röhl, U., Warnaar, J. and Williams, G.L., in press. Timing and nature of the deepening of the Tasmanian Gateway. Paleoceanography.

Stover, L.E., 1977. Oligocene and early Miocene dinoflagellates from Atlantic corehole 5/5b, Blake Plateau. In: Elsik, W.C. (Ed.), Contributions of Stratigraphic Palynology. 1: Cenozoic Palynology. Contributions Series - American Association of Stratigraphic Palynologists vol. 5A, pp. 66-89.

Stover, L.E., Hardenbol, J., 1994. Dinoflagellates and depositional sequences in the lower Oligocene (Rupelian) Boom clay formation, Belgium. Bulletin van de Belgische Vereniging voor Geologie/Bulletin de la Sociéte Belge de Geologie, T. 102 (1-2), $5-77$.

Stover, L.E., Brinkhuis, H., Damassa, S.P., de Verteuil, L., Helby, R.J., Monteil, E., Partridge, A., Powell, A.J., Riding, J.B., Smelror, M., Williams, G.L., 1996. Mesozoic-Tertiary dinoflagellates, acritarchs and prasinophytes. In: Jansonius, J., McGregor, D.C. (Eds.), Palynology: Principles and Applications. American Association of Stratigraphic Palynologists Foundation, Dallas, pp. 641-750.

Suess, E., 1980. Particulate organic carbon flux in the oceanssurface productivity and oxygen utilization. Nature 288, $260-263$.

Tappan, H., Loeblich, A.R.J., 1971. Geobiologic implications of fossil phytoplankton evolution and time-space distribution. In: Kosanke, R.M., Cross, A.T. (Eds.), Symposium on palynology of the late Cretaceous and early Tertiary. Special Paper Geological Society of America 127, 247-340.

Targarona, J., Warnaar, J., Boessenkool, K.P., Brinkhuis, H., Canals, M., 2000. Recent dinoflagellate cyst distribution in the north Canary Basin, NW Africa. Grana 38 (2/3), 170-178.

Taylor, F.J.R. (Ed.), 1987. The Biology of Dinoflagellates, Botanical Monographs vol. 21. Blackwell Scientific Publications, London, 785 pp.

Taylor, D.L., Seliger, H.H., 1979. Toxic Dinoflagellate Blooms. Elsevier, North Holland, 505 pp.

Thomas, E., Shackleton, N.J., 1996. The Palaeocene-Eocene benthic foraminiferal extinction and stable isotope anomalies. In: Knox, R.W.O.B., Corfield, R.M., Dunay, R.E. (Eds.), Correlation of the Early Paleogene in Northwestern Europe, Special Publication - Geological Society of London 101, 401-441.

Trench, R., 1987. Non-parasitic symbioses. In: Taylor, F.J.R. 
(Ed.), The Biology of Dinoflagellates. Botanical Monographs, pp. $530-570$.

Turon, J.-L., 1981. Le palynoplancton dans l'environnement actuel de l'Atlantique Nord oriental. Evolution climatique et hydrologique depuis le Dernier Maximum Glaciaire. Thèse d'Etat Thesis, Université de Bordeaux, 313 pp.

Vandenberghe, N., Brinkhuis, H., Steurbaut, E., 2003. The Eocene/Oligocene boundary in the North Sea area: a sequence stratigraphic approach. In: Prothero, D.R., Ivany, L.C., Nesbitt, E.A. (Eds.), From Greenhouse to Icehouse: the Marine Eocene Oligocene Transition. Columbia Univ. Press, New York, pp. 419-437.

van Mourik, C.A, Brinkhuis, H., 2000. Data report: organic walled dinoflagellate cyst biostratigraphy of the latest middle to late Eocene at Hole 1053A (Subtropical Atlantic Ocean). In: Kroon, R.D., Norris, R.D., Klaus, A. (Eds.), Proceedings of the Ocean Drilling Program. Scientific Results vol. 171B, pp. 1-25. Available from World Wide Web: http://www-odp.tamu.edu/ publications/171B_SR/chap_06/chap_06.htm.[Cited 2000-0908], College Station, TX.

van Mourik, C.A., Brinkhuis, H., Williams, G.L., 2001. Middle to late Eocene organic walled dinoflagellate cysts from ODP Leg 171B, offshore Florida. In: Kroon, D., Norris, R.D., Klaus, A. (Eds.), Western North Atlantic Palaeogene and Cretaceous Palaeoceanography. Special Publication - Geological Society of London 183, 225-251.

van Simaeys, S., Brinkhuis, H., Pross, J., Williams, G.L., and Zachos, J.C., submitted for publication. Global dinoflagellate migration marks the Oligocene Glacial Maximum. Geology.

Versteegh, G.J.M., 1994. Recognition of cyclic and non-cyclic environmental changes in the Mediterranean Pliocene: a palynological approach. Marine Micropaleontology 23, 147-183.

Versteegh, G.J.M., Zonneveld, K.A.F., 1994. Determination of (palaeo-)ecological preferences of dinoflagellates by applying Detrended and Canonical Correspondence analysis to late Pliocene dinoflagellate cyst assemblages of the south Italian Singha secion. Review of Palaeobotany and Palynology 84 , $181-199$.

Versteegh, G.J.M., Zonneveld, K.A.F., 2002. Use of selective degradation to separate preservation from productivity. Geology 30 (7), 615-618.

von Benedek, P.N., Gocht, H., 1981. Thalassiphora pelagica (Dinoflagellata, Tertiär): elektronenmikroskopische Untersuchung und Gedanken zur Paläobiologie. Palaeontographica (B) 180, 39-64.

Vonhof, H.B., Brinkhuis, H., Van der Hoeven, M., Smit, J., Montanari, A., Nederbragt, A.J., 2000. Global cooling accelerated by early late Eocene impacts. Geology 28, 687-690.

Wall, D., Dale, B., 1974. Dinoflagellates in late Quaternary deep-water sediments of Black Sea. In: Degens, E.T., Ross, D.A. (Eds.), The Black Sea-Geology, Chemistry and Biology. Memoir - American Association of Petroleum Geologists, pp. $364-380$.

Wall, D., Dale, B., Harada, K., 1973. Descriptions of new fossil dinoflagellates from the late Quaternary of the Black Sea. Micropaleontology 19, 18-31.

Wall, D., Dale, B., Lohmann, G.P., Smith, W.K., 1977. The envi- ronmental and climatic distribution of dinoflagellate cysts in the North and South Atlantic and adjacent seas. Marine Micropaleontology 30, 319-343.

Wefer, G., Berger, W.H., Bijma, J., Fischer, G., 1999. Clues to ocean history: a brief overview of proxies. In: Fischer, G., Wefer, G. (Eds.), Use of Proxies in Paleoceanography, Examples from the South Atlantic. Springer, Berlin, pp. 1-68.

Williams, G.L., 1977. Dinoflagellate cysts, their classification, biostratigraphy and palaeoecology. In: Ramsay, A.T.S. (Ed.), Oceanic Micropalaeontology. Academic Press, London, pp. $1231-1325$.

Williams, G.L., Brinkhuis, H., Pearce, M.A., Fensome, R.A., Weegink, J.W., 2004. Southern Ocean and global dinoflagellate cyst events compared; index events for the late CretaceousNeogene. In: Exon, N.F., Kennett, J.P., Malone, M.J. (Eds.), Proceedings of the Ocean Drilling Program. Scientific Results vol. 189, pp. 1-98. Available from World Wide Web: <http:// www-odp.tamu.edu/publications/189_SR/107/107.htm>. [Cited 2004-04-09]. College Station, TX.

Wilpshaar, M., Santarelli, A., Brinkhuis, H., Visscher, H., 1996. Dinoflagellate cysts and mid-Oligocene chronostratigraphy in the central Mediterranean region. Journal of the Geological Society (London) $153,553-561$.

Wolff, T., Grieger, B., Hale, W., Dürkoop, A., Mulitza, S., Pätzold, J., Wefer, G., 1999. On the reconstruction of paleosalinities. In: Fischer, G., Wefer, G. (Eds.), Use of Proxies in Paleoceanography. Examples from the South Atlantic. Springer, Berlin, pp. $207-228$.

Wrenn, J.H., Beckmann, S.W., 1982. Maceral, total organic carbon, and palynological analyses of Ross Ice Shelf Project site J9 cores. Science 216, 187-189.

Wrenn, J.H., Hart, G.F., 1988. Paleogene Dinoflagellate Cyst Biostratigraphy of Seymore Island, Antarctica. In: Feldmann, R.M., Woodburne, M.O. (Eds.), Geology and Paleontology of Seymour Island, Antarctic Peninsula. Memoirs of the Geological Society of America, 321-447.

Zachos, J.C., Pagani, M., Sloan, L.C., Thomas, E., Billups, K., 2001. Trends, rhythms, and aberrations in global climate 65 Ma to present. Science 292, 686-693.

Zachos, J.C., Wara, M.W., Bohaty, S., Delaney, M.L., Petrizzo, M.R., Brill, A., Bralower, T.J., Premoli Silva, I., 2003. A transient rise in tropical sea surface temperature during the Paleocene-Eocene Thermal Maximum. Science 302, 1151-1154.

Zevenboom, D., 1996. Late Oligocene-early Miocene dinoflagellate cysts from the Lemme-Carrosio section (NW Italy); biostratigraphy and palaeoenvironmental interpretation. In: Steininger, F.F., Iaccarino, S., Cati, F. (Eds.), In search of the Paleogene-Neogene boundary; Part 3, The global stratotype section and point, the GSSP for the base of the Neogene (the Paleogene-Neogene boundary). Giornale di Geologia 58, (1-2), 81-93.

Zevenboom, D., Brinkhuis, H., Visscher, H., 1994. Dinoflagellate cysts palaeoenvironmental analysis of the Oligocene/Miocene transition in northwest and central Italy. In: Coccioni, R., Montanari, A., Odin, G.S. (Eds.), Miocene Stratigraphy of Italy and Adjacent Regions. Giornale di Geologia 56, 1, 155-169. 


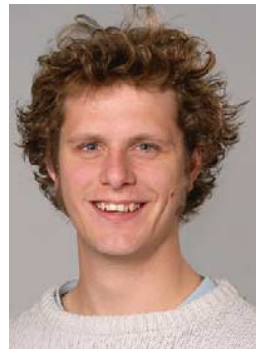

Appy Sluijs is a PhD student at the Department of Palaeoecology, Laboratory of Palaeobotany and Palynology at Utrecht University, The Netherlands. His main research interests include extreme climate transitions, their nature and their effects on the biosphere. His Masters at Utrecht University comprized dinocyst and inorganic geochemistry analysis (in cooperation with the University of California at Santa Cruz) on material from the EoceneOligocene transition of the Tasmanian Gateway. His $\mathrm{PhD}$ research is focused on unraveling the history of brief intervals of global warming in the early Paleogene (e.g., PETM and MECO) combining organic walled dinocyst information, stable isotope geochemistry and other proxies.

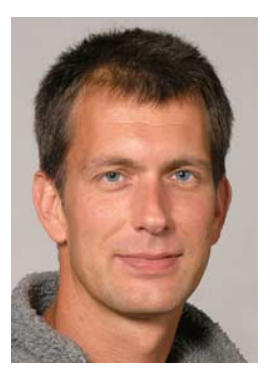

Jörg Pross is a lecturer at the Institute of Geosciences, Tübingen University, Germany. From October 2004, he will hold a professorship for micropaleontology and paleoceanography at Frankfurt University, Germany. His research focuses on paleoenvironmental and paleoclimatic reconstructions based on palynomorphs from both the marine and terrestrial realms, with an emphasis on the Cenozoic. Presently, Jörg Pross is also a visiting senior researcher at the Laboratory of Palaeobotany and Palynology at Utrecht University, The Netherlands, where he cooperates with Appy Sluijs and Henk Brinkhuis on the paleoenvironmental significance of Oligocene dinocysts from the Southern Ocean recovered during Leg 189 of the Ocean Drilling Program.

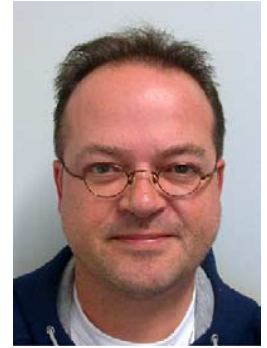

Henk Brinkhuis is a senior lecturer at the Department of Palaeoecology, Laboratory of Palaeobotany and Palynology at Utrecht University, The Netherlands. His research interests include Cretaceous-Cenozoic global change, notably extreme climate transitions, and related biostratigraphy, (paleo)ecology, (paleo)provinvicialism, biochemistry, etc. of phytoplankton and of (organic walled) dinoflagellate(s) (cysts) in particular. 